LIVIA MARIA DE SOUZA ROCHA

\title{
ESTUDO ANATOMO-ANESTESIOLÓGICO DO SEGMENTO LOMBAR (L1 A L6) EM CÃES
}

$$
\begin{gathered}
\text { SÃO PAULO } \\
2003
\end{gathered}
$$




\section{LÍVIA MARIA DE SOUZA ROCHA}

DEDALUS - Acervo - FMVZ

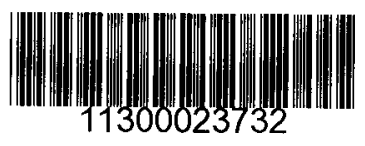

\section{ESTUDO ANATOMO-ANESTESIOLÓGICO DO SEGMENTO LOMBAR (L1 A L6) EM CÃES}

Dissertação apresentada para obtenção do título de Mestre, junto à Faculdade de Medicina Veterinária e Zootecnia da Universidade de São Paulo.

Departamento:

Cirurgia

Área de concentração:

Anatomia dos Animais Domésticos

Orientador:

Prof. Dr. Flávio Massone

Acervo - FMV2 022593

\begin{tabular}{|c|}
\hline $\begin{array}{l}\text { N. CLASSIFICACAO } \\
\text { t. } 1197 \\
\text { Fin } 127 \\
0.2\end{array}$ \\
\hline N.O TOMBO \\
\hline 22593 \\
\hline
\end{tabular}


Autorizo a reproduçăo parcial ou total desta obra, para fins acadêmicos, desde que citada a fonte.

DADOS INTERNACIONAIS DE CATALOGAÇÃO-NA-PUBLICAÇĀO

(Biblioteca da Faculdade de Medicina Veterinária e Zootecnia da Universidade de S3o Paulo)

T.1197 Rocha, Livia Maria de Souza

FMVZ Estudo anatomo-anestesiológico do segmento lombar (L1 a L6) em cães / Livia Maria de Souza Rocha. - São Paulo : L. M. S. Rocha, 2003.

$81 \mathrm{f}$ : : il.

Dissertação (mestrado) - Universidade de São Paulo. Faculdade de Medicina Veterinária e Zootecnia. Departamento Cirurgia, 2003.

Área de concentração: Anatomia dos Animais Domésticos.

Orientador: Prof. Dr. Flávio Massone.

1. Anestesia. 2. Cirurgia. 3. Anatomia. 4. Cães. I. Título. 


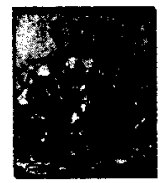

\author{
UNIVERSIDADE DE SÃO PAULO \\ Faculdade de Medicina Veterinária e Zootecnia \\ Cidade Universitária "Armando de Salles Oliveira" \\ Comissão de Bioética
}

\title{
CERTIFICADO
}

Certificamos que o Projeto intitulado "Estudo anatomo-anestesiológico do espaço peridural via lombo-sacral em cães", Protocolo $\mathrm{n}^{\mathrm{o}}$ 217/2002, sob a responsabilidade do Prof. Dr. Flávio Massone, está de acordo com os princípios éticos de experimentação animal da Comissão de Bioética da Faculdade de Medicina Veterinária e Zootecnia da Universidade de São Paulo e foi aprovado pela referida Comissão, em sessão de 30/10/2002.

(We certify that the Research "Anatomical and anesthesological study of peridural space in lombosacral way in dogs " protocol number 217/2002, under the responsability of Prof.Dr. Flávio Massone, agree with Ethical Principles in Animal Research adopted by Bioethic Commission of the Faculty of Veterinary Medicine and Zootechny of University of São Paulo and was approved in 10/30/2002 meeting.

São Paulo, 04 de novembro de 2002

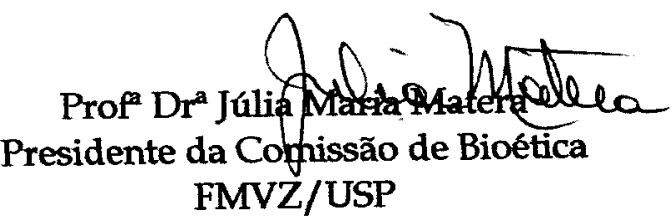

Av. Prof. Orlando Marques de Paiva, 87 - 05508-900 - Cla. Univ. "Armando de Salles Olvelra" Fone/Fax: (011) 3032-2224 / 3091-7671 / 3091-7676 


\section{FOLHA DE APROVAÇÃO}

Nome do autor: ROCHA, Lívia Maria de Souza
Título: Estudo Anatomo-anestesiológico do.Segmento Lombar (L1 a L6) em cães.

Dissertação apresentada à Faculdade de Medicina Veterinária e Zootecnia da Universidade de são Paulo para obtenção do título de Mestre em Anatomia.

Aprovado em:

Banca Examinadora

Prof. Dr. Feario Mlossome Julgamento: a freverb
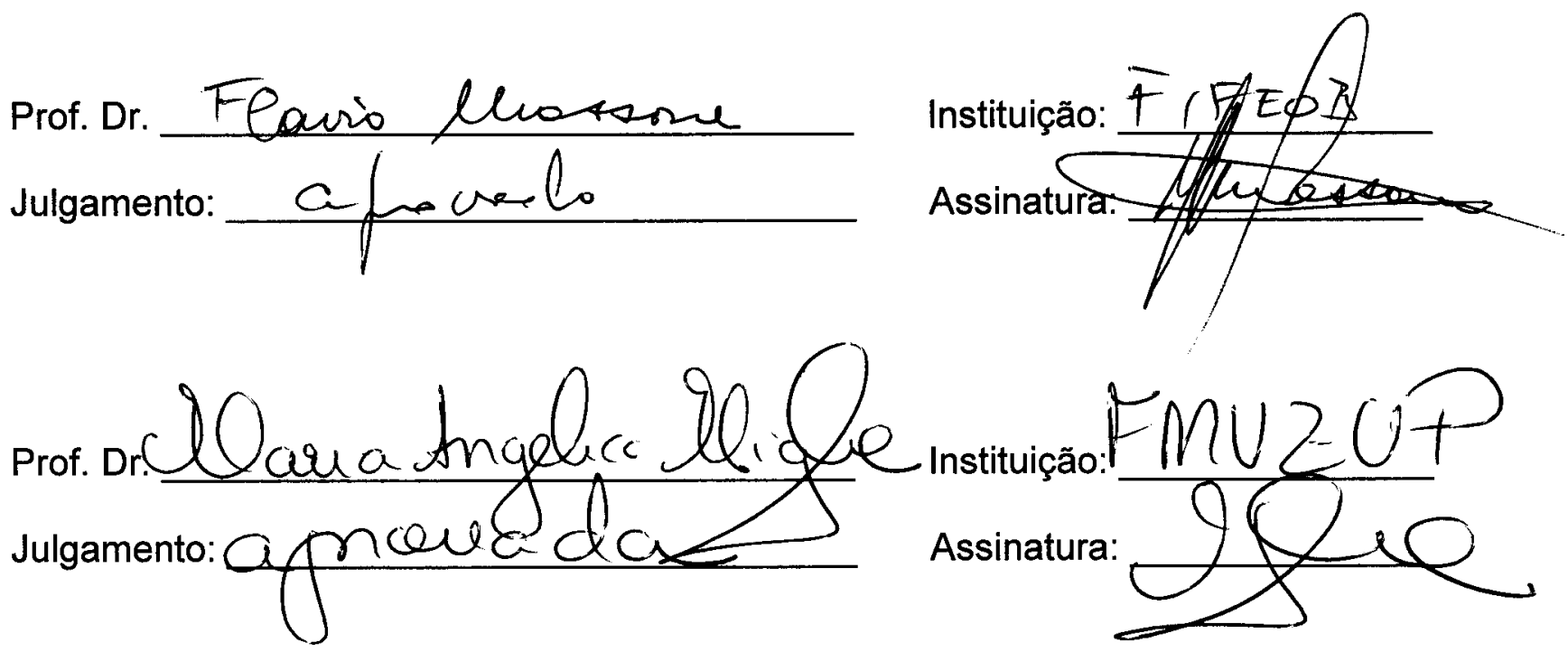

Prof. Dr. Andreís PPPl. Aoncalus

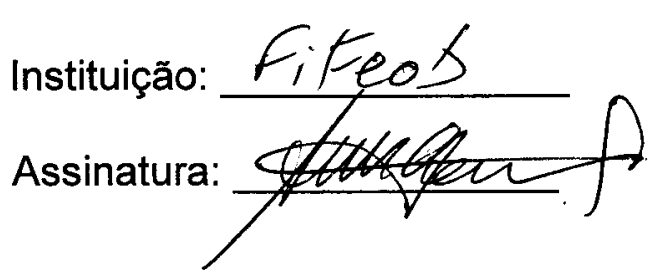




\section{DEDICATÓRIA}

Dedico este trabalho a meu marido, William, que nesta jornada foi meu companheiro, amigo, irmão e pai. Pela paciência em meus momentos dificeis, pela compreensão em minha ausência nos momentos de trabalho árduo, pelas palavras nos momentos de desânimo, pelo apoio na criação de nossos filhos, pela ajuda na manufatura deste projeto, e, principalmente, pela sua maravilhosa presença em todos estes momentos. 


\section{AGRADECIMENTOS}

Aos meus amados filhos, Rodolpho e Mariana, pela compreensão nos momentos de ausência e impaciência.

À minha querida mãe, sem a qual não teria conseguido chegar até aqui.

À Professora Maria Angélica Miglino, pelo apoio, incentivo e compreensão em tudo o que precisei.

Ao Professor Flávio Massone, pela orientação, amizade e ensinamentos, não só técnicos, mas também vivenciais.

Ao Ricardo, Marquinhos, Dona Aninha, enfim, todos os funcionários do Setor de Anatomia, pela valiosa colaboração.

Às Faculdades Integradas da Fundação de Ensino Octávio Bastos, pelo incentivo.

À Professora Priscila Carvalho de Oliveira, diretora do Hospital onde trabalho, pela paciência e compreensão.

A todos aqueles que, direta ou indiretamente colaboraram com este projeto. 


\section{LISTA DE ILUSTRAÇÕES}

\section{Página}

Figura 1. Peça anatômica, previamente preparada, pronta para o início da dissecação

Figura 2. Organograma da distribuição dos ramos nervosos lombares

Figura 3. Nervo esplâncnico maior, que se insinua na cavidade abdominal, saindo do segmento lombar $\mathrm{T}_{13}$

Figura 4. Nervos esplâncnicos menores, emergindo caudalmente, ao nervo esplâncnico maior, suprindo a aorta e plexo celíaco-mesentérico

Figura 5. Nervos esplâncnicos lombares saindo de $L_{1}$ e $L_{3}$ deixando o tronco simpático caudalmente ao nervo esplâncnico maior e emitindo filamentos para a aorta, glândula adrenal e plexo celíacomensentérico

Figura 6. Quinto e sexto nervos esplâncnicos lombares dirigindo-se diretamente para o plexo mesentérico caudal e emitindo ramos para os nervos hjipogástricos

Figura 7. Aspecto morfológico macroscópico do plexo adrenal, plexo celíaco mesentérico, recebendo contribuição das fibras dos nervos esplâncnicos menores e dos três primeiros nervos esplâncnicos lombares

Figura 8. Aspecto morfológico do plexo mesentérico caudal se originando da artéria mesentérica caudale ligando-se ao plexo pélvico 
Figura 9. Fibras nervosas emergindo de suas raízes ventrais e travando sinapses em tecidos alvo e glândulas abdominais 64

Figura 10. Fibras nervosas emergindo de suas raízes ventrais e travando sinapses em tecidos alvo e glândulas abdominais 64

Figura 11. Fibras nervosas emergentes de $L_{1}$ e $L_{3}$ se insinuando entre os ligamentos abdominais destacando-se os ligamentos ovarianos e uterinos na fêmea

Figura 12. Aspecto geral dos nervos espinhais lombares destacando-se o nervo íleo-hipogástrico cranial, íleo-hipogástrico caudal, íleo-inguinal e femoral cutâneo lateral 65

Figura 13. Aspecto geral dos nervos espinhais lombares destacando-se o nervo íleo-hipogástrico cranial, íleo-hipogástrico caudal, íleo-inguinal, femoral cutâneo lateral, femoral e obturador 66

Figura 14. Últimos nervos esplâncnicos lombares se unindo ao plexo lombar 66

Figura 15. Plexo lombar, nervo femoral e nervo obturador 67

Figura 16. Plexo lombar, vista aproximada 67

Figura 17. A saída do nervo íleo-hipogástrico cranial de $L_{1}$, nervo íleo-hipogástrico caudal de $L_{3}$ formando os dois primeiros pares de nervos lombares 68

Figura 18. Nervo íleo-inguinal emergindo em $L_{3}$, nervo femoral cutâneo lateral emergindo em $L_{5}$, femoral emergindo entre $L_{5}$ e $L_{96}$ e obturador emergindo em $L_{6}$ 68

Figura 19. Nervo femoral emergindo entre $L_{5}$ e $L_{6}$, nervo obturador emergindo entre $L_{6}$ e $L_{7}$ e nervo 
isquiático emergindo de $\mathrm{L}_{7}$

Figura 20 . Nervo femoral emergindo entre $L_{5}$ e $L_{6}$, nervo obturador emergindo entre $L_{6}$ e $L_{7}$ e nervo isquiático emergindo de $\mathrm{L}_{7}$ e $\mathrm{S}_{1}$

Figura 21. Vista geral do tronco esplâncnico lombar do SNA e seus respectivos ramos e plexos alvo 
ROCHA, L. M. S. Estudo anatomo-anestesiológico do segmento lombar (L1 a L6) em cães. [Anatomo-anesthaesiological study of the lumbar segment in dogs] São Paulo, 2002. 81 f. Tese (Mestrado) Faculdade de Medicina Veterinária e Zootecnia, Universidade de São Paulo.

Foram realizadas dissecações seriadas desde as raízes nervosas e suas respectivas inervações viscerais, concernentes ao Sistema Nervoso Autônomo, simpático e parassimpático, em cadáveres, a fresco, de cães, sem raça definida, de diferentes tamanhos e pesos, ao longo dos espaços lombossacrais, iniciando-se a dissecação em $L_{1}$ e finalizando-a em $S_{2}$.

Os aspectos levados em consideração para a análise morfofuncional destas inervações visaram a orientação para o emprego da anestesia local espinhal peridural, tão empregada em anestesiologia veterinária especialmente em se visando pacientes toxêmicos, gestantes ou de alto risco ao se utilizar esta anestesia efetuada por injeção utilizando-se agulha de Twoy, através do espaço lombossacral, manobra esta fácil mas que conta ainda com certas restrições pela falta de prática. 
ROCHA, L. M. S. Anatomo-anesthaesiological study of the lumbar space (L1 a L6) in dogs. [Estudo anatomo-anestesiológico do espaço lombar (L1 a L6) em cães]. São Paulo, 2002. 81 f. Tese (Mestrado) Faculdade de Medicina Veterinária e Zootecnia, Universidade de São Paulo.

Serial dissections were accomplished from the nervous roots and their respective visceral innervations, concerning to the Autonomous Nervous System, sympathetic and parasympathetic, in corpses, to fresh, of dogs, without defined race, of different sizes and weights, along the lumbossacral spaces, beginning the dissection in L-1 and concluding this, in S-2.

The aspects taken into account for the morfofunctional analysis of these innervations to certify the orientation to apply the local spinal peridural anesthesia, that so help in veterinary anesthesiology, especially in toxemic, pregnant or high risk patients, when the use this anesthesia, made by injection using Twoy needles, through the lumbossacral space, an easy procedure, but that still exist restrictions because the unpractice. 


\section{SUMÁRIO}

Página

RESUMO

SUMMARY

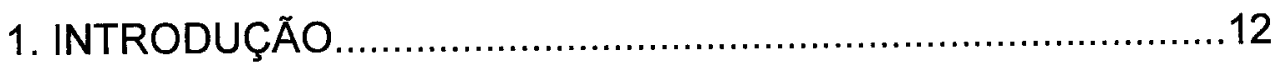

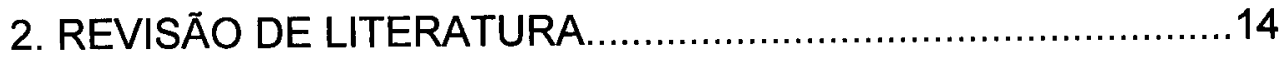

2.1. Sistema Nervoso Central..............................................14

2.2. Medula Espinhal.........................................................16

2.3. Sistema Nervoso Autônomo..............................................22

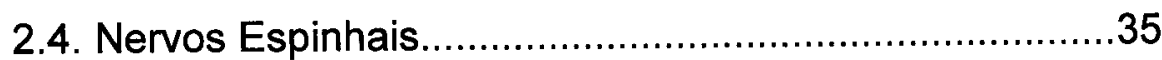

2.5. Anestesia local via espaço epidural em cães..................49

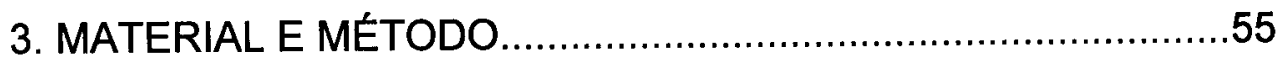

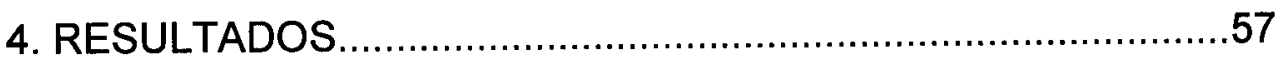

5. DISCUSSÃO

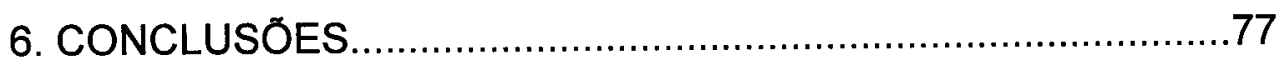

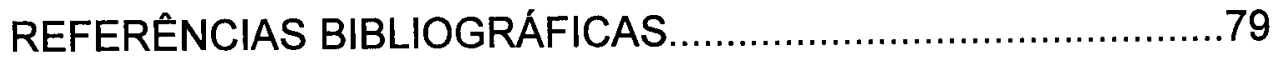




\section{INTRODUÇÃO}

Em cirurgia, muitas vezes a anestesia se torna um obstáculo para a realização de atos que, em várias situações são cruciais para a vida do animal, visto que, a depressão cardíaca e respiratória causada por anestésicos gerais chega a ser proibitiva para pacientes de alto risco, com problemas pré-existentes nestes sistemas, (idosos ou neonatos e gestantes).

Nestes casos a anestesia peridural tem sido uma alternativa para procedimentos cirúrgicos caudais ao diafragma, em cães que são classificados como pacientes de alto-risco para anestesia geral. Entretanto, sabe-se que a administração de fármacos no espaço epidural promove também, algumas alterações sistêmicas que podem ser significativas em animais não hígidos, colocando em risco a segurança da técnica. Portanto, o conhecimento acurado da anatomia, histologia e fisiologia do sistema nervoso a este nível se torna crucial para o uso da técnica com toda a segurança e precauções necessárias.

Outro fator importante a ser considerado é muitas vezes o desconhecimento da distribuição da inervação e a repercussão da anestesia dos mesmos sobre o sistema nervoso simpático e parassimpático. Objetivase fazer um estudo anatômico metamérico da coluna lombar e sacral em cães, possibilitando mapear todo o trajeto das raízes nervosas envolvidas, bem como suas ramificações e órgãos alvo atingidos. 
O que se tem observado no decorrer destes anos, é que, as anestesias locais espinhais peridurais lombossacras, têm sido evitadas, não pela falta de praticidade, mas sim pelo receio do seu emprego ou mesmo pelo desconhecimento anatômico em seus segmentos lombares.

Sabe-se, atualmente que o simples emprego da anestesia local espinhal lombossacra, não é suficiente para se realizarem ovariosalpingohisterectomias, ou mesmo cesarianas, pois não ocorre a anestesia no ligamento lienovárico, o que causa dor e desconforto no paciente, pois esta anestesia não atinge metâmeros mais craniais.

O estudo anatômico desta região se faz necessário, pois, orientaria de forma mais segura o anestesista através da introdução de cateter no espaço peridural via lombossacra, permitindo menor risco para o paciente, com maior efetividade anestésica.

Esta justificativa permite objetivar este trabalho no sentido de se estudarem, anatomicamente, a distribuição nervosa das raízes eferentes de três segmentos definidos $\left(L_{1}, L_{3}\right.$ e $\left.L_{6}\right)$ buscando-se no futuro o aspecto anestesiológico. 


\section{REVISÃO DE LITERATURA}

\subsection{Sistema Nervoso Central}

SISSON e GROSSIMAN (1978) descrevem o Sistema Nervoso "como um mecanismo complexo, mediante o qual o organismo se comporta em relação com o mundo exterior, e, por meio do qual, se coordena a função de suas diversas partes". O cordão espinhal e o cérebro constituem o sistema nervoso central. O cordão espinhal fica enclausurado no canal vertebral, formado por uma série de ossos protetores (as vértebras cervicais, torácicas e lombares) dispostos de maneira a formar este canal ou conduto funcional (CUNNINGHAM, 1999), onde estão as raízes espinhais dorsal e ventral que pertencem ao sistema nervoso periférico.

Através das raízes e nervos espinhais, a medula inerva o tronco e cauda, os membros e a superfície caudal e dorsal da cabeça. Dentro do canal espinhal, os nervos motores e sensitivos estão separados; os nervos sensitivos penetram na medula espinhal através das raízes nervosas dorsais, e transmitem impulsos sensoriais (aferentes) para a medula, enquanto que, os nervos motores deixam a medula espinhal por meio das raízes ventrais que carreiam a saída de respostas através de impulsos (eferentes) vindos da medula para músculos e glândulas. (CUNNINGHAM, 1993; FLETCHER, 1999).

De acordo com DYCE (1996) "o sistema nervoso central é uma comunicação de duas vias virtualmente com todos os tecidos corpóreos por meio de um sistema de ramificação de nervos periféricos". 
O Sistema Nervoso informa animal sobre seu ambiente, ambos interno e externo e inicia respostas àquele ambiente. Outros sistemas corporais são especializados para sustentar a vida executando funções, como locomoção, digestão, respiração, e circulação, e é essencial que estas funções sejam reguladas e coordenadas pelo sistema nervoso. As células que constituem o sistema nervoso são altamente especializadas para estímulos receptores, por meio de receptores em órgãos do sentido, altamente especializados, por transmitir e armazenar informação, e por iniciar respostas a esses estímulos.

As células que compõem o sistema nervoso são de dois tipos: neurônios (células nervosas), que recebem e transmitem informações; e células da glia que sustentam mantêm os neurônios no lugar e impedem os impulsos nervosos de se dispersarem entre as células nervosas que não são unidas através de sinapse. O Sistema Nervoso, formado por estes dois tipos de células é conectado ao tecido vascular, e é subdividido em Sistema Nervoso Central (SNC), consistindo no cérebro (encéfalo) e espinha dorsal (medula espinhal), e o Sistema Nervoso Periférico (SNP), composto de nervos cranianos e espinhais. As divisões são arbitrárias porque, partes do mesmo neurônio podem estar no SNC e no SNP. O termo nervo é aplicado a uma estrutura total que consiste em processos periféricos de células nervosas ligadas em série e envoltas por tecido conjuntivo. Gânglio é o termo aplicado a uma coleção de corpos de células nervosas, de estrutura esférica envolto por tecido conjuntivo associado com um nervo, fora do SNC. Fibra nervosa é um termo utilizado para descrever um processo 
microscópico de uma célula nervosa. As estruturas, contidas dentro do SNC estão localizadas dentro da membrana neuroglial do cérebro ou da espinha dorsal; assim, as raízes e gânglios, normalmente ilustrados com o SNC pertencem ao SNP e não ao SNC. O tecido nervoso é dividido em massa branca e cinzenta, baseado na aparência de partes frescas seccionadas do SNC. A massa cinzenta consiste principalmente em corpos de células nervosas, neuroglia, dendritos e axônios entrelaçados, mielinizados e não mielinizados. A parte branca consiste em fibras de mielinizadas dispostas longitudinalmente e neuroglia associada.(KITCHELL, 1993).

\subsection{Medula Espinhal}

DYCE (1996), descreve a medula espinhal como sendo: - "uma estrutura alongada, mais ou menos cilíndrica, mas com algum achatamento dorso-ventral e determinadas variações regionais de forma e dimensões. As mais importantes dessas variações são os espessamentos (intumescências) das partes que dão origem aos nervos que suprem os membros anteriores (torácico) e posteriores (pélvico) e o afilamento final caudal (cone medular). A medula é dividida em segmentos correspondentes aos somitos por origens seriadas das raízes dos nervos espinhais pares. O encéfalo e a medula espinhal ficam contidos dentro de um espaço contínuo conferido pela cavidade do crânio e pelo canal formado por sucessivos anéis ósseos e ligamentos e discos de união da coluna vertebral. O canal vertebral é mais largo dentro do Atlas e vai diminuindo rapidamente dentro do sacro; ao longo de seu comprimento, expande-se mais onde contém as intumescências 
cervical e lombar da medula espinhal, das quais emergem os nervos que formam os plexos dos membros".

A topografia da medula espinhal é de importância muito considerável na clínica veterinária, já que freqüentemente aplicam-se injeções no canal, em particular de solução anestésica local, com a finalidade de bloquear nervos espinhais específicos. Mesmo com as inclusões de seus envoltórios meníngeos, a medula espinhal é consideravelmente menor do que o canal vertebral. Também é consideravelmente mais curta. $\mathrm{O}$ desvio relativo na posição (ascensus medullae) leva os segmentos da medula cranialmente com relação a suas posições originais dentro das vértebras de mesmas designações numéricas. O desvio dos segmentos mais caudais é mais pronunciado e explica o arranjo peculiar de nervos espinhais associados. Estes assumem trajetos progressivamente mais longos dentro do canal, indo alcançar seus forames fixos de saída e formando uma cauda (conhecida como cauda eqüina por sua semelhança superficial com a cauda de um cavalo) para cada lado do cone medular.

O nível em que a medula termina varia entre as espécies e com a idade. No cão ocorre em $L_{6}-L_{7}$. Através do canal vertebral a medula e as raízes espinhais são "envelopadas" por três camadas (membranas) protetoras contínuas chamadas de meninges, que apresentam determinadas diferenças topográficas importantes em suas partes craniais e vertebrais. A rígida membrana mais externa a dura-máter é fibrosa e forte e (DYCE, 1996; FLETCHER, 1993), funde-se com o periósteo mais interno dos ossos do crânio; separa-se deste no forame magno, formando um tubo livre separado 
do canal vertebral por um espaço epidural amplo, embora variável. O espaço epidural fica ocupado por tecido adiposo, mais líquido em vida que na amostra obtida após a morte, e pelo plexo venoso vertebral interno; o tecido adiposo e os vasos em conjunto protegem a medula espinhal e servem para ajustar os movimentos do pescoço e do dorso.

O tubo dural é fixado em sua extremidade caudal, onde as diversas meninges finalmente combinam-se com um cordão fibroso (filamento terminal), que se funde na superfície superior das vértebras caudais. A fusão da dura máter craniana com o periósteo oblitera o espaço epidural dentro do crânio e seios venosos cranianos ficam, dessa forma, embutidos dentro da espessura da membrana composta. Além de recobrir a cavidade a duramáter craniana forma determinadas pregas que se projetam para dentro e limitam os movimentos oscilatórios do encéfalo. Um espaço capilar separa a dura-máter da aracnóide, a primeira das duas membranas internas mais delicadas. (DYCE, 1980; SCHIMIDT et al, 1993; MAILHAC et al, 1996).

DELLMANN e McCLURE, 1975, descrevem a Medula Espinhal dos carnívoros: "a intumescência cervical inclui o quinto segmento da medula espinhal cervical até o segundo segmento da medula espinhal torácica. A intumescência lombar tem início no quarto segmento lombar e termina no segundo segmento sacral com a medula espinhal afunilando-se até o cone medular. A medula espinhal termina muito próximo da junção da sexta e sétima vértebras lombares. O tamanho e o formato, em corte transversal, da medula espinhal do canino variam em diferentes níveis. $O$ trato corticospinhal compõe $10 \%$ da substância branca da medula espinhal no 
cão. As fibras do trato corticospinhal estão distribuídas ou terminam na medula espinhal conforme segue: para a parte cervical $50 \%$; para a parte torácica $20 \%$, e para a parte lombar $30 \%$. Sobre as meninges citam que, "no cão, o filamento da dura-máter espinhal está inserido no periósteo do canal espinhal da sétima ou oitava vértebras caudais. A cavidade subaracnóidea termina caudalmente no nível da primeira vértebra sacral. Os tubos da dura-máter espinhal, que circundam as raízes dorsal e ventral dos nervos espinhais, estão normalmente aderidos um ao outros nos primeiros cinco segmentos cervicais. As serrações do ligamento denticulado da pia máter são grandes e estendem-se caudalmente até o primeiro segmento sacral da medula espinhal. A última serração insere-se na dura-máter ao nível do corpo da quinta vértebra lombar, entre o quinto e o sexto nervos espinhais lombares".

A medula espinhal é quase circular em secção transversal, exceto nas intumescências cervical e lombar, onde está comprimida dorsoventralmente. O cone medular se acha em cima da união da sexta e sétima vértebras lombares. A extensão da medula em cães mede em média 38 centímetros; destes 11 centímetros correspondem à região cervical, 17,4 centímetros à região torácica, sete centímetros á região lombar e 2,6 centímetros à região sacrococcígea. (SISSON e GROSSMAN, 1978).

KITCHELL (1993), reporta que: "na medula espinhal dorsal, a massa cinzenta forma a parte central, com a parte branca envolvendo a massa cinzenta. Dentro da massa cinzenta, estão os corpos celulares de neurônios com funções semelhantes ficam freqüentemente situados em colunas ou em 
agrupamentos de células chamados núcleos funções. A massa cinzenta da espinha dorsal é organizada em colunas longitudinais que em secção transversa têm a aparência de cornos, chamados cornos dorsais, laterais, e ventrais. Os corpos de celulares de neurônios motores inferiores estão agrupados em núcleos motores nos cornos ventrais. Nas regiões lombares e torácicas superiores da espinha dorsal, os corpos celulares de neurônios pré-ganglionares simpáticos ficam situados em uma coluna celular intermediária, a parte lateral que se projeta para formar o corno lateral. $\mathrm{Na}$ região sacral da espinha dorsal, corpos celulares de outros neurônios do Sistema Nervoso Autônomo se situam na coluna celular intermediária formando o núcleo parassimpático sacral (não o corno lateral). A massa branca da espinha dorsal é subdividida em cada metade do cordão espinhal em três funículos, o funículo dorsal, o funículo lateral, e o funículo ventral (também chamado de colunas brancas). O funículo dorsal está separado do funículo lateral pela entrada de fibras da raiz dorsal que são os processos centrais de fibras aferentes primárias. O funículo lateral está separado do funículo ventral pela saída das fibras eferentes".

As porções centrais de fibras aferentes primárias na raiz dorsal, entram na espinha dorsal e se ramifica para percorrer cranialmente e caudalmente distâncias variadas (i. e., eles nunca terminam em só um segmento). Como conseqüência disto, eles emitem muitas ramificações colaterais que entram na massa cinzenta do corno dorsal. Estes ramos colaterais de fibras aferentes formam muitos milhares de sinapses com intemeurônios, com projeções de neurônios, e, algumas vezes, com 
neurônios eferentes. Conexões multissinápticas e monossinápticas significam sinapses entre um ou dois (ou mais) neurônios conectados em série como numa cadeia. Todas as fibras aferentes têm muitos milhares de sinapses "em paralelo". Os corpos celulares de neurônios eferentes alfa (geralmente chamados de neurônios motores inferiores) se agrupam para formar núcleos na massa cinzenta da do cérebro ou em núcleos localizados no corno ventral da espinha dorsal. Os axônios destes neurônios emitem freqüentemente uns ramos colaterais, chamados de colateral recurrente, dentro da massa cinzenta próximo da origem do axônio, e então o axônio deixa o SNC para formar a raiz ventral que faz parte do SNP. Este axônio é a fibra eferente somática geral encontrada nos nervos periféricos. Termina se ramificando e formando placas motoras em várias fibras de musculares (chamadas fibras de músculo de extrafuso), constituindo uma unidade motora. Os corpos celulares eferentes gama são encontrados em locais semelhantes ao dos neurônios motores inferiores. Os neurônios eferentes gama provêem fibras musculares pequenas, chamados fibras intramusculares, onde há receptores de extensão especializados localizados entre as fibras musculares. Os corpos celulares de fibras de eferentes beta terminam em fibras musculares intrafuso e extra fuso.

A significância das fibras nervosas beta eferentes está obscura pois os neurônios autônomos são ligados em série. O primeiro neurônio da série se refere a um neurônio pré-ganglionar, com seu pequeno corpo celular multipolar localizado no SNC e seu processo condutivo periférico (fibra préganglionar) se estendendo perifericamente para travar sinapse com números 
variados de neurônios pós-ganglionares localizados em um gânglio autônomo. (KITCHELL, 1993).

FLETCHER \& CUNNINGHAM (1993, 1999), observaram que, "quanto à função, a medula espinhal executa três operações gerais, a saber: - via conexão de nervos espinhais, processa informações aferentes vindas de músculos, tendões, articulações, ligamentos, pele, e vísceras, e, descarrega comandos eferentes que controlam músculos e regulam glândulas; - a medula espinhal é um centro de reflexo, produzindo respostas subconscientes de músculos e glândulas por estímulos especiais; - a medula espinhal conduz informações para o cérebro e vindas do cérebro através de um sistema de rede de fibras, pelas quais o cérebro recebe categorias de informação sobre o tronco e membros enquanto distribui comandos que controlam postura, movimento e aspectos viscerais de comportamento".

SCHIMIDT et al (1993), cita ainda: "o espaço epidural pode ser facilmente acessado por punção, através do forâmen lombo-sacro"

\subsection{Sistema Nervoso Autônomo}

O Sistema Nervoso Autônomo (SNA) é um conceito funcional. O SNA é um sinônimo para neurônios eferentes viscerais gerais. Alguns autores consideram neurônios eferentes viscerais gerais como parte do sistema nervoso autônomo pela sua importância no reflexo víscera-víscera. Incluir os aferentes viscerais gerais no SNA é negligenciar o fato de que de também há reflexos somato-viscerais que envolvem os aferentes viscerais gerais e fibras do eferente. O SNA se difere anatomicamente do outro 
sistema eferente no fato de que seus dois neurônios são unidos em sinapse em série num sistema autônomo de gânglios. O primeiro neurônio da cadeia tem seu corpo celular dentro do SNC e é chamado de neurônio préganglionar. A fibra pré-ganglionar é mielinizada e possui de 2 a 7 ųm de diâmetro no cão. Os corpos celulares das fibras pré-ganglionares, estão localizadas em centros chamados de núcleos, ou colunas celulares. O corpo celular do segundo neurônio na cadeia está localizado no gânglio autônomo periférico. A fibra nervosa é não mielinizada e chamada de fibra pósganglionar.

O SNA é subdividido em duas partes, parassimpático (pars parasympathica) e simpática (pars sympathica), em anatomia, fisiologia e farmacologia. A divisão parassimpática tem os corpos celulares do neurônio pré-ganglionar localizada na região cranial e sacral do SNC, enquanto que o sistema simpático tem os corpos celulares dos seus neurônios préganglionares localizados na região do corno lateral nas regiões lombares e torácicas superiores da medula espinhal. O sinônimo para a divisão parassimpática do SNA é divisão crânio-sacral; o sinônimo para a divisão simpática do SNA é divisão toraco-lombar. Em ambos os sistemas as fibras pré ou pós ganglionares se projetam em áreas onde nenhuma outra fibra pré-ganglionar emerge do SNC. A ativação do SNA simpático, em geral, produz um efeito de "massa", enquanto que a ativação do sistema parassimpático produz efeitos mais "localizados". A estimulação do parassimpático produz efeitos catabólicos, ou mantém o estado normal, enquanto que, a estimulação do simpático produz efeitos anabólicos de "Iuta 
ou fuga". As fibras pós ganglionares abastecem músculos lisos do leito vascular ao longo do corpo, exceto dentro do SNC. Para alcançar o leito vascular, as fibras pós ganglionares pegam "carona" correndo várias distâncias em quase todos os nervos periféricos (incluindo suas ramificações) e ao longo de vasos sanguíneos, formando plexos ao redor dos vasos. Se aquele nervo periférico é seccionado (exceto o olfatório, ótico, e nervos vestibulococleares) o controle neural daquele leito vascular será perdido. Recentemente, mais informação foi revelada sobre o sistema nervoso intramural. Esta é a rede de neurônios aferentes e eferentes que são encontrados nas paredes de órgãos abdominais. Foi demonstrado que os neurônios aferentes nesta parte do sistema nervoso, nunca adentram o SNC, mas ao invés disso, eles travam sinapse em núcleos pós ganglionares nas paredes do intestino (gânglio terminal) ou, em alguns locais, em gânglios intermediários de ambos, simpático e parassimpático, separados do sistema nervoso autônomo. (KITCHELL, 1993).

Sendo o sistema nervoso autônomo dividido em dois sistemas, o parassimpático e o simpático, a porção cranial do hipotálamo contém corpos celulares dos neurônios parassimpáticos que descendem e fazem sinapse no núcleo do tronco cerebral associado com os nervos cranianos oculomotor, facial, glossofaríngeo e vago, e na medula espinhal na massa cinzenta, nos segmentos sacrais $S_{1}$ a $S_{3}$. A porção caudal do hipotálamo contém os corpos celulares dos neurônios simpáticos que descendem e fazem sinapse na coluna cinzenta intermediolateral da medula espinhal nos segmentos toracolombar $T_{1}$ a $L_{3}$. Esses neurônios autônomos descendentes 
são chamados de neurônios de primeira ordem, e servem para modular a atividade dos neurônios periféricos autônomos. Os estímulos reflexos locais também modulam a atividade dos neurônios autônomos periféricos. O sistema nervoso autônomo periférico é composto de uma cadeia de dois neurônios. Os corpos celulares no neurônio pré-ganglionar (neurônio de segunda ordem) estão localizados no tronco cerebral ou massa cinzenta da medula espinhal, e seus axônios saem da medula espinhal pelos nervos cranianos motores ou raízes ventrais dos nervos espinhais para fazer sinapse nos corpos celulares do neurônio pós-ganglionar (neurônio de terceira ordem) em gânglios afastados. Os neurônios pós-ganglionares inervam, então, seus tecidos alvos, tanto músculos liso ou cardíaco, como glândulas do organismo. (CHRISMAN, 1985).

JONES et al, 1996 cita que: "o sistema nervoso autônomo compreende nervos aferentes e eferentes inervando vísceras". Já DYCE, 1996 cita que: "embora a regulação adequada das atividades "viscerais" sugira claramente a existência de receptores nas vísceras e vasos, originariamente o sistema nervoso autônomo foi definido como totalmente eferente". Comenta ainda que: "este fato, de certa forma é conveniente, já que as vias aferentes viscerais são em geral indistinguíveis, em termos de estrutura e arranjo, de seus pares somáticos, já as vias eferentes viscerais, são nitidamente distintas, em particular pela localização no último neurônio na cadeia dentro de um gânglio periférico e pela restrição dos neurônios que conduzem estas células ganglionares para núcleos específicos do tronco encefálico e regiões particulares da medula". 
A função principal primária do Sistema Nervoso Autônomo, a manutenção da homeostase através do controle da circulação, respiração, excreção e manutenção da temperatura corpórea. Essas funções reguladoras estão sujeitas a modificações por comandos de centros cerebrais altos, especialmente nos casos de reações ambientais. A via eferente visceral consiste de um par de neurônios ao contrário de um neurônio simples como ocorre no sistema nervoso somático. O corpo celular do primeiro neurônio está no tronco cerebral ou medula espinhal. Seu axônio termina no corpo celular do segundo neurônio, localizado num gânglio autonômico. O axônio do gânglio termina na célula efetora. (BENSON et al, 1996.

Aferentes viscerais autonômicos são, primariamente, neurônios sensoriais, similares àqueles em tecidos somáticos. Eles provocam respostas reflexas nas vísceras e uma sensação de amplitude em órgãos cavitários como estômago, intestinos e vesícula. Impulsos aferentes contribuem para sensações de bem-estar ou mal-estar e conduzem impulsos de dor.Aferentes viscerais especiais modulam sensações especiais de funções gustativas e olfatórias. Os aferentes viscerais gerais têm os seus corpos celulares em gânglios sensoriais de nervos craniais e espinhais incluindo a saída autonômica. Esses neurônios são de dois tipos: aferentes fisiológicos e aferentes de dor. Os aferentes fisiológicos estão presentes em ambas as divisões, parassimpática e simpática, enquanto que, os aferentes de dor são quase que exclusivamente simpáticos. O aferente visceral fisiológico mais importante está associado com a divisão parassimpática e 
modula os reflexos cardiovasculares, respiratórios e gastrintestinais. Os aferentes viscerais de dor são associados à divisão simpática. Os corpos celulares estão localizados na raiz ganglionar toraco-lombar dorsal. Seus processos periféricos alcançam o tronco simpático via ramo comunicante branco, percorre o tronco simpático e alcança a víscera através dos nervos cardíacos, pulmonares e esplâncnicos.

As terminações centrais estão nas células transmissoras na substância gelatinosa e o caminho ascendente para dor visceral coincide pelo menos em parte com aquele para dor somática. O hipotálamo é a área cerebral primária que controla o sistema nervoso autônomo. O sistema nervoso autônomo pode ser subdividido em crânio sacral ou divisão parassimpática e toraco-lombar ou divisão simpática. A característica do sistema nervoso autônomo é que ambas as divisões estão constantemente ativas, resultando em níveis basais de tônus simpático e parassimpático. Assim cada divisão pode aumentar ou diminuir seus efeitos para dar ao órgão funções mais estritamente reguladas. (BENSON et al, 1996; DYCE, 1996).

STROMBERG, 1993, em seu capítulo do Sistema Nervoso Autônomo, cita que: "numerosos documentos que datam desde 1811 descrevem inervação simpática extensa de ligamentos associados com a coluna vertebral". MULLINGAN (1957) apud STROMBERG é da opinião que fibras simpáticas terminam entre as fibras de colágeno que envolve estes ligamentos no cão. 
Gânglios autônomos são classificados como vertebral (paravertebral), colateral (pré-vertebral), e terminal (periférico). Gânglios vertebrais são mais ou menos segmentalmente distribuídos ao longo das cadeias simpáticas emparelhadas que, em contrapartida, ficam, em parte ao longo do lado ventral da cabeça dos membros. São achados gânglios colaterais mais perifericamente e, na cavidade abdominal são relacionados a algumas das artérias maiores, como a celíaca. Gânglios terminais são usualmente pequenos e situados em vários órgãos do corpo. Neurônios entéricos, da parede intestinal que podem ser aferentes em função, e, então, possivelmente, tem um papel importante no reflexo de peristaltismo, e, talvez, de dor. Impulsos aferentes viscerais possuem papel importante nestes reflexos, e, a maioria desses impulsos, não dá origem a sensações em seres humanos. Nós deveríamos permanecer atentos que não existe nenhum meio para determinar sensações subjetivas em animais $\mathrm{s}$, e assim, nós, às vezes, recorremos a experiência e sentimentos pessoais para interpretação. (STROMBERG, 1993).

Axônios pré-ganglionares partem das raízes ventrais dos segmentos sacrais. Estas fibras se unem, mais distalmente com os nervos pélvicos, situados na parede lateral da porção distal do reto. O nervo pélvico é provido de fibras pré-ganglionares, principalmente de neurônios de segmentos sacrais 1, 2, e 3 (SAMSON e REDDY, 1982). Em ambos os lados o nervo pélvico se expande em um plexo que também recebe o nervo hipogástrico (simpático). Um ou mais gânglios (presumivelmente parassimpáticos) ficam situado dentro do plexo. A distribuição de fibras pós- 
ganglionares autônomas é feita através de ramos e plexos à vísceras pélvicas e órgãos reprodutivos. Foram localizadas fibras parassimpáticas da região sacral pelo comprimento do intestino grosso. Pesquisa relatada por FUKAI e FUKUDA em 1985 sugere que, a inervação parassimpática do cólon, consiste em três neurônios em cadeia, com o neurônio pré-ganglionar da espinha dorsal sacral, um neurônio pós-ganglionar no plexo pélvico, e ainda um terceiro neurônio no plexo miontérico. Origem de fibras parassimpáticas que influenciam a bexiga urinária, estão em segmentos sacrais para caudais (PURINTON e OLIVER, 1979). Atividade aferente visceral da uretra, reto, e genitália, alcançam a espinha dorsal pelo nervo pélvico e é retransmitido então ao córtex cerebral. Atividade aferente da vesícula urinária a medula através de nervos pélvicos e hipogástricos, mas só atividade neural posterior é retransmitida ao córtex cerebral (PURINTON et al. , 1981).

Ramos do tronco simpático torácico e abdominal inervam fibras préganglioniares simpáticas torácicas e fibras simpáticas das regiões abdominais e pélvicas. Além disso, estes ramos também levam algumas fibras pós-ganglionares e, um número considerável de fibras aferentes viscerais. O nervo esplâncnico torácico (maior) deixa o tronco simpático torácico aproximadamente ao nível do décimo terceiro gânglio torácico. O nervo é maior, em diâmetro que a continuação do tronco simpático. Ambos passam abaixo do arco lombocostal lateral para cruzar o diafragma e entrar na cavidade abdominal. Outros ramos designados como nervos esplâncnicos menores, podem deixar 0 tronco simpático apenas 
caudalmente ao nervo esplâncnico maior. O nervo esplâncnico torácico manipula filamentos à aorta torácica e a glândula supra-renal. Termina, principalmente como vários ramos no plexo celíaco-mesenterico. A cadeia ganglionar renal também pode ser provida por este nervo. Os nervos esplâncnicos menores, se presentes, se distribuem à mesma área geral. Às vezes podem ser achados filamentos de ligação do esplâncnico maior para o primeiro nervo esplâncnico lombar.

Imediatamente depois que o nervo esplâncnico torácico se ramificar, o tronco simpático lombar se torna delgado, mas fica maior conforme caminha caudalmente. A cadeia ganglionar pode estar presente em cada um dos sete segmentos lombares, ou fusão variável da cadeia adjacente pode acontecer. Contribuições pré-ganglionares para o tronco simpático lombar não acontecem, aparentemente, nunca caudal a $L_{6}$. Na maioria das vezes, limites caudais das inervações pré-ganglionares são em $L_{4}$ ou $L_{5}$.

Nervos esplâncnicos lombares podem surgir de cada um dos níveis segmentários simpáticos lombares, esses, dos primeiro cinco podem ser muito constantes. Eles são nomeados de acordo com o nível do qual surgem. A maioria se origina como filamento único, mas alguns podem ser duplos, e ramos anastomóticos podem unir nervos adjacentes. A origem pode ser de um gânglio lombar ou de segmentos interganglionares do tronco simpático. Como citado anteriormente, o primeiro nervo esplâncnico lombar pode ter conexões com o nervo esplâncnico torácico. Em geral, os primeiros quatro nervos esplâncnicos lombares se distribuem a um ou mais dos seguintes plexos: aórtico-renal, mesentérico cranial, e gânglio gonadal; 
intermesentérico, renal, e plexos gonadais. Ramos que surgem do gânglio aórtico-renal provêem terminações adrenérgicas, encontrados no aferente glomerular, arteríolas eferentes e próximos das células da mácula densa do rim. O quinto a sétimo nervos esplâncnicos lombares vão para o gânglio mesentérico caudal. Filamentos também vão para a veia cava caudal e artérias ilíacas. São achados plexos correspondentes de complexidade variável ao longo das artérias da região abdominal. Estes, a raiz do celíaco e artérias mesentéricas craniais formam um tapete denso ou envoltura chamada de plexo celíaco mesentérico. Isto se continua com o plexo, que é distribuído com as ramificações destas duas artérias. Entrelaçado no plexo celíacomesentérico está o celíaco, emparelhado à cadeia ganglionar mesentérica cranial.

Gânglios simpáticos pequenos cada um contendo aproximadamente 25 a 100 neurônios, têm sido demonstrados ao longo do curso das artérias maiores da cavidade abdominal. Desde que estes fiquem distais a gânglios maiores como o celíaco e mesentérico cranial, pode ser esperado que contenham algumas fibras pré-ganglionares simpáticas, além da preponderância de pós-ganglionare simpáticas. Este plexo também inclui fibras pré-ganglionares parassimpáticas e fibras aferentes viscerais. A cobertura celular da medula da glândula adrenal e os mediadores químicos envolvidos indicam que esta porção das glândulas supra-renais são muito semelhantes a um gânglio simpático. (STROMBERG, 1993).

A medula é ricamente inervada por fibras pré-ganglionares que se originam de $\mathrm{T}_{4}$ ou $\mathrm{T}_{5}$ e de $\mathrm{L}_{1}$ ou $\mathrm{L}_{2}$ no cão (CUMMINGS, 1969). 
Filamentos que seguem as artérias ilíacas externas e internas podem surgir aparentemente localizadas caudalmente aos nervos esplâncnicos lombares, nervos hipogástricos, e, como continuações do plexo aórtico. Os nervos hipogástrico direito e esquerdo representam conexões pósganglionares, em grande parte. entre o gânglio mesentérico caudal e o plexo pélvico. Eles são, usualmente, nervos grossos e dissecáveis. A parte caudal do ureter é inervada através de nervos hipogástricos e pélvicos, considerando que a parte rostral é inervada pelo nervo vago e fibras simpáticas sobre o controle de células na medula espinhal dorsal de $T_{10}$ a

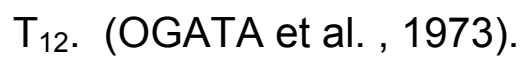

O segmento abdominal do tronco simpático é espesso e uniforme. Os gânglios lombares são em número de cinco ou seis. Pode ocorrer um certo grau de comunicação entre eles, muitas vezes, o primeiro e o segundo gânglios lombares e o sexto e o sétimo estão fundidos e variam no tamanho e no formato. Os ramos comunicantes são subdivididos e estão dispostos ao lado dos vasos que inervam. Em geral, unem-se aos nervos espinhais próximo ao forame intervertebral. Os nervos esplâncnicos lombares surgem dos gânglios lombares ou dos ramos interganglionares do tronco simpático abdominal. Estão presentes nos primeiros cinco segmentos lombares e podem ser únicos ou subdivididos. Muitas vezes, o primeiro nervo esplâncnico está ligado ao nervo esplâncnico maior e vai para os gânglios aórtico-renal e mesentérico cranial; o segundo contribui para o mesentérico cranial, testicular ou ovariano acessório. O quarto nervo esplâncnico lombar contribui para o plexo testicular e ovariano próprio. O quinto vai diretamente 
para o plexo mesentérico caudal. O sexto e o sétimo além de ir para o plexo mesentérico caudal, ocasionalmente estendem-se diretamente para o plexo pélvico através dos nervos hipogástricos. (GOSHAL, 1975).

No que diz respeito aos principais plexos e gânglios autônomos da cavidade abdominal, GOSHAL, 1975, descreve:

- "o plexo adrenal (supra-renal) é uma densa rede de filamentos entre a face profunda da glândula adrenal e o pilar do diafragma. Os gânglios adrenais estão distribuídos por todo o plexo e recebem fibras do nervo esplâncnico maior, nervos esplâncnicos menores.

- o plexo celíacomesentérico aparece como uma rede fibrosa que circunda as origens da artéria celíaca e mesentérica cranial. O gânglio celíaco e gânglio mesentérico cranial, separados, situam-se ao longo da superfície caudal da origem da artéria celíaca. Recebem contribuições do nervo esplâncnico maior, menores e dos primeiros três nervos esplâncnicos lombares. As fibras parassimpáticas pré-ganglionares atingem o plexo celíacomesentérico através dos troncos vagais dorsais.

- os gânglios aórtico-renais estão intimamente ligados ao plexo celíacomesentérico e aos gânglios celíaco e mesentérico cranial. Eles derivam fibras do nervo esplâncnico maior, e do primeiro nervo esplâncnico lombar.

- o plexo renal é formado de ramos que surgem dos gânglios esplâncnicos lombares e aórtico-renais ou somente dos gânglios aórtico-renais. Filamentos correm através da porção extra-renal da artéria renal e penetram no rim. 
- o plexo testicular pode ser dividido em uma parte própria e outra acessória. O plexo testicular próprio está relacionado a artéria testicular e contém o gânglio testicular. O acessório surge do plexo aórtico abdominal e contém um gânglio testicular acessório.

- o plexo ovariano na fêmea é o homólogo do anterior. Ele também consiste em uma parte própria e outra acessória. O plexo ovariano próprio está associado à artéria ovariana e um gânglio ovariano. O plexo ovariano acessório pode conter um gânglio ovariano acessório e está formado pelo plexo aórtico abdominal.

- o plexo mesentérico caudal circunda a origem da artéria mesentérica caudal. Cranialmente ele se continua com o plexo mesentérico cranial, e, caudalmente, com o plexo pélvico. Há um pequeno e alongado gânglio mesentérico caudal em relação a origem da artéria correspondente. O plexo normalmente deriva suas fibras do plexo aórtico abdominal e dos nervos esplâncnicos lombares mais caudalmente localizados. Os ramos viscerais correm, com os ramos da artéria mesentérica caudal, para a distribuição periférica.

- o plexo aórtico abdominal é bem desenvolvido e está relacionado lá superfície ventrolateral da aorta abdominal. A porção deste plexo que se estende pelo plexo mesentérico caudal e celíacomesentérico e os gânglios do mesmo nome é denominada plexo intermesentérico. Este compreende um grupo de fibras longas e paralelas. O plexo aórtico abdominal recebe contribuições dos gânglios celíacos direito e esquerdo, dos gânglios aórticorenal, variavelmente, dos primeiro quatro nervos esplâncnicos lombares e, 
também, das fibras vagais dorsais, plexo mesentérico, e gânglios celíaco e mesentérico cranial."

\subsection{Nervos Espinhais}

EVANS \& KITCHELL, 1993, afirmaram que: "os nervos espinhais são, normalmente, constituídos no cão de 36 pares. Cada nervo espinhal consiste em quatro segmentos, de proximal para distal: (1) raízes, (2) tronco principal, (3) quatro primeiras ramificações, e (4) numerosos ramos periféricos".

Por outro lado, GHOSHAL, 1975, quando cita em seu capítulo os nervos espinhais do cão, diz que: "os nervos espinhais totalizam 35 ou 38 pares: cervicais (8); torácicos (13), lombares (7), sacrais (3) e caudais ou coccígeos (quatro a sete) e; os nervos lombares são em número de sete pares. Eles emergem do canal vertebral através do forame intervertebral, caudalmente às vértebras correspondentes. Como outros nervos espinhais, cada nervo lombar se divide em um ramo dorsal e outro ventral.

Os ramos dorsais são relativamente delgados e subdividem-se em um ramo medial (essencialmente muscular) e lateral (cutâneo); entretanto, nos últimos três ou quatro nervos lombares os ramos dorsais podem não se dividir distintamente nos ramos medial e lateral. Os ramos laterais, como os nervos craniais das nádegas, inervam a pele das superfícies dorsolaterais das regiões lombar e sacral".

As raízes ficam dentro do canal vertebral e consistem em uma raiz dorsal (radix dorsalis) com um gânglio espinhal (spinale ganglion), e uma 
raiz ventral (radix ventralis). O tronco principal fica em grande parte situado dentro do forame intervertebral. Dentro do forame intervertebral, o tronco principal emite um pequeno e variável ramo meningeo (ramus meningeus).

Após emergir do forame intervertebral, o tronco principal emite um ramo dorsal (ramus dorsalis), então um ramo comunicante (ramus communicans), e continua como um grande ramo ventral (ramus ventralis). Os ramos dorsais e ventrais normalmente se subdividem em ramos mediais e ramos laterais que dão origem a numerosos ramos menores. As raízes dorsais e ventrais são encontradas através do canal vertebral; o gânglio espinhal (raiz dorsal) fica situado à junção das raízes dorsal e ventral, próximo do forame intervertebral. Cada raiz dorsal e ventral consiste de várias inervações, ou filamentos de raiz (fila radicularia). As inervações dorsais enviam fibras através da medula espinhal através do sulco dorsolateral. As inervações ventrais emergem da medula espinhal a um amplo e indistinto sulco ventrolateral. Nem as raízes dorsais nem as raízes ventrais são unidades compactas. Elas consistem em feixes frouxamente unidos de fibras nervosas que são difíceis de se diferenciar um do outro, por causa da cobertura transparente da membrana aracnóide. O número de filamentos da raiz dorsal é parecido com o número de filamentos da raiz ventral para cada nervo espinhal.

O número de filamentos da raiz dorsal e ventral é em média seis para cada um dos primeiros cinco nervos cervicais. Eles aumentam em tamanho e em número para uma média de sete dorsais e sete filamentos ventrais do quinto segmento cervical caudal até o segundo segmento torácico. Do 
segundo segmento torácico até o décimo terceiro segmento torácico há dois filamentos dorsais e dois filamentos ventrais que formam cada raiz de nervo torácico. Cada raiz dorsal e ventral é envolta perto da espinha dorsal por pia máter e membranas aracnóides internas e então, embebida por fluido cérebro-espinhal no espaço de subaracnóide. Esta porção de segmento de uma raiz nervosa freqüentemente é chamado de segmento intradural. Mais distalmente, uma raiz nervosa entra em um tubo de meninges formado pela camada externa da membrana aracnóide e a dura máter. Este segmento de é freqüentemente chamado de segmento extradural de uma raiz nervosa espinhal, um termo um pouco enganoso porque o tubo de meninges consiste em três camadas de meninges, inclusive o pequeno espaço subaracnóide contendo fluido cerebrospinal. No gânglio da raiz dorsal, as meninges continuam no tronco principal como o epineuro.

Pelo fato de a coluna vertebral e a espinha dorsal continuarem crescendo depois do nascimento, o tamanho total da espinha dorsal é menor que o comprimento do canal vertebral; assim, os últimos nervos lombares , sacrais, e os nervos da cauda têm de percorrer distâncias crescentemente mais longas antes de alcançarem o forame intervertebral correspondente para sair do canal vertebral. Estas raízes têm segmentos intradurais mais longos que os extradurais que as outras raízes mais craniais. Desde a parte caudal da espinha dorsal (caudalmente a S-I) e os nervos que deixam este segmento se assemelham a uma cauda de cavalo, esta parte da espinha dorsal (conus medullaris), com suas respectivas raízes espinhais, é 
chamado de cauda eqüina. A cauda eqüina faz parte do sistema nervoso periférico.

O gânglio espinhal (ganglia spinalia), geralmente chamado gânglio da raiz dorsal, são agregações de corpos celulares pseudounipolares que ficam situados na raiz dorsal (raramente externamente) próximos forame intervertebral correspondente. Os axônios das células pseudounipolares se dividem em processos centrais e periféricos. Esses axônios periféricos se misturam com os axônios dos filamentos da raiz ventral formando o tronco principal de um nervo espinhal que, assim, contém ambas as fibras sensitivas (aferentes) e motoras (eferentes), geralmente chamado de "nervo misto". (EVANS e KITCHELL, 1993).

Os nervos periféricos compreendem os doze pares de nervos cranianos e o número consideravelmente maior de pares de nervos espinhais, cujo total varia com a fórmula vertebral. O cão possui oito pares cervicais, 13 torácicos, sete lombares, três sacrais e cerca de cinco caudais. A origem ordenada dos nervos espinhais revela a segmentação da medula espinhal. Cada nervo é formado pela união de duas raízes. A raiz dorsal é composta quase que exclusivamente de fibras aferentes, cujos corpos celulares estão agrupados em conjunto para formar uma tumefação visível, o gânglio espinhal (raiz dorsal). Os processos centrais adentram a medula ao longo do sulco dorso lateral. Os processos periféricos estendemse a partir da ampla variedade de terminações exteroceptivas, proprioceptivas e enteroceptivas que respondem aos estímulos externos, alterações dentro dos músculos e outros órgãos locomotores e modificações 
nos órgãos internos, respectivamente. A raiz ventral é composta exclusivamente de fibras eferentes emanando dos neurônios motores dentro do corno ventral da substância cinzenta e saindo da medula ao longo de uma linha ventrolateral; elas ficam na passagem para os órgãos efetores músculos e glândulas. As raízes dorsal e ventral juntam-se na periferia da raiz dorsal do gânglio para formar o nervo espinhal misto, que deixa o canal vertebral pelo forame intervertebral apropriado. Na região cervical, cada nervo emerge cranial à vértebra da mesma designação numérica que o nervo, exceto o oitavo, que emerge entre a última vértebra cervical e a primeira torácica; nas outras regiões, cada nervo emerge caudal à vértebra da mesma designação numérica.

O tronco misto formado pela união entre as raízes dorsal e ventral divide-se quase que imediatamente em ramos dorsal e ventral. O ramo dorsal distribui-se para as estruturas dorsais: músculos epiaxiais do tronco (de modo amplo, aqueles que ficam dorsais aos processos transversos), e a pele do dorso. O ramo ventral muito maior se distribui para os músculos hipoaxiais do tronco (de forma ampla, aqueles ventrais aos processos transversos), músculos dos membros (com poucas exceções) e parte remanescente da pele, inclusive aquela dos membros. Tanto os ramos dorsal como o ventral apresentam conexões com seus vizinhos, que formam plexos contínuos dorsal e ventral. Estes plexos, em geral, não são nem óbvios nem importantes, exceto pelas porções aumentadas do plexo ventral oposto às origens dos membros. Esses, os plexos braquial e lombossacral, dão origem aos nervos que se distribuem para as estruturas dos membros 
anterior (torácico) e posterior (pélvico), respectivamente. O plexo braquial geralmente é formado por contribuições dos últimos três nervos cervicais e dos dois primeiros nervos torácicos, o plexo lombossacral por contribuições dos poucos últimos nervos lombares e dos dois primeiros nervos sacrais.

Os plexos dos membros permitem reagrupamento e reassociação das fibras nervosas constituintes e os troncos nervosos que emergem distalmente são, cada um deles, compostos de fibras derivadas de dois ou três segmentos espinhais; portanto, o nervo mediano compõe-se de fibras dos nervos espinhais $C_{8}$ e $T_{1}$, o nervo femoral, de fibras de $L_{4}-L_{6}$.

Os trajetos dos troncos periféricos principais devem ser conhecidos para evitar colocar os nervos sob riscos desnecessários durante cirurgias. Suas conexões centrais são importantes em dois contextos. Primeiro: soluções anestésicas locais injetadas próximas dos nervos espinhais selecionados possuem efeitos previsíveis na paralisia dos músculos e em privar áreas cutâneas da sensação. Ao contrário, a paralisia de músculos particulares ou sensibilidade ausente ou alterada de áreas cutâneas específicas aponta a localização exata de uma lesão central. Por outro lado a inervação de vasos sanguíneos, glândulas e órgãos internos são feitas pela divisão autônoma do sistema nervoso, chamado de "Sistema Nervoso Autônomo" ou "vegetativo, visceral e/ou involuntário". Isto porque suas ações não necessitam de consciência para serem controladas. Neste aspecto ele entra em contraste com o sistema nervoso somático que inerva e controla a musculatura estriada. (DYCE, 1996). 
Os nervos lombares são em número sete de cada lado. Cada membro de um par emerge do forame intervertebral cranialmente à vértebra correspondente.

O meio do primeiro segmento lombar do cordão espinhal se localiza dorsalmente ao disco intervertebral, entre a primeira e a segunda vértebras lombares. As raízes nervosas do primeiro par de nervos lombares, portanto, se localiza, essencialmente na mesma área, transversal ao forame de saída destes nervos. Como caudalmente, os segmentos da espinha dorsal são menores que os segmentos vertebrais, o cordão espinhal termina no disco intervertebral entre a sexta e sétima vértebra lombar. Por este comprimento desproporcional, - as raízes dorsais e ventrais dos últimos pares de nervos espinhais percorrem distâncias crescentemente mais longas dentro do canal espinhal antes de deixar seus confinamentos ósseos que corresponde ao forame intervertebral correspondente aos nervos espinhais craniais a eles. $\mathrm{O}$ feixe de nervos assim formados é chamado de cauda eqüina.

O tronco principal dos nervos espinhais lombares é formado pela fusão das raízes dorsais e ventrais ao forame intervertebral. Como as raízes dos vários nervos espinhais lombares correm caudalmente, suas partes proximais se localizam dentro da cobertura dural da espinha dorsal, e suas partes distais se localizam em tubos meníngeos na gordura epidural. Como os nervos espinhais típicos das regiões precedentes, cada nervo espinhal lombar se divide para deixar o forame intervertebral em quatro ramos primários: um pequeno e variável ramo meníngeo; um pequeno ramo comunicante dorsal; e um ramo ventral maior. O comprimento do tronco 
principal de cada nervo espinhal lombar é só de alguns poucos milímetros, e se localiza em grande parte dentro e um pouco lateral ao forame intervertebral pelo qual passa.

O ramo dorsal (primário) (ramus dorsales) dos nervos lombares são semelhantes ao longo da maior parte desta região. Como os nervos torácicos, cada um deles se divide tipicamente, em ramos mediais e laterais. Os ramos mediais (ramus mediales) se ramificam no músculo longíssimus lombar, o qual eles inervam, e envia ramos terminais ao músculo multífudo lombar e músculos interespinhais lombares. Eles correm obliquamente em direção caudo-dorsal pela superfície lateral dos processos espinhosos das vértebras caudais a eles. Eles estão separados das bordas ventrais dos tendões do músculo longíssimo lombar, que vai para os processos acessórios da vértebra lombar pelos grandes ramos do ramo dorsal das artérias do segmento lombar. Nenhum ramo cutâneo dorsal surge dos ramos medianos dos ramos primários dorsais.

Os ramos laterais (ramus lateralis) dos ramos dorsais dos primeiros três ou quatro nervos lombares estão claramente separados dos ramos medianos. Os ramos dorsais dos últimos três ou quatro nervos lombares não se dividem claramente em porções mediais e laterais, mas eles ramificamse nos músculos epaxiais lombares. Os ramos laterais dos ramos dorsais dos primeiros três ou quatro nervos lombares correm caudolaterais pelo músculo longissimus e íleocostal e atravessam médio-lateralmente íleocostal de modo segmentar. Eles provêem a parte lombar do músculo íleocostal. Depois de continuar em uma direção caudolateral no tecido 
areolar, um centímetro ou mais abaixo da fáscia lombodorsal, eles atravessam a fáscia lombodorsal e se ramificam na pele nas partes dorsolaterais das regiões lombares e sacrais como os ramos cutâneos dorsais. Os ramos cutâneos dorsais dos nervos lombares se referem aos nervos cranianos cluniais, tais como: nervo clunial cranial, e nervos cluniais superiores (terminologia da Nômina Anatômica), conforme citação de KITCHELL e EVANS em 1993.

Os ramos cutâneos dos ramos dorsais na região lombar, variam, pois, podem ou não ser um ramo cutâneo dorsal para o quarto nervo lombar (BAILEY et al, 1984, 1988,; HAGHIGHI et al. , 1991).

Em alguns espécimes o ramo cutâneo dorsal do sétimo nervo lombar se junta aos ramos cutâneos dorsais dos nervos espinhais sacrais, para ajudar a formar os nervos de cluniais medianos (BAILEY et al , 1988)

Nos nervos espinhais lombares, que não possuem ramos cutâneos dorsais, não é possível diferenciar ramos mediais e laterais; ao invés dos ramos musculares surgirem, eles se dissipam na musculatura epaxial, sem a primeira divisão em partes mediais e laterais.O tronco principal de cada nervo espinhal lombar é conectado ao tronco simpático, com raras exceções, por um ramo comunicante. Os ramos comunicantes podem ser duplos, ou o ramo de dois nervos adjacentes pode ir para o mesmo gânglio. Os primeiros quatro ou cinco ramos contêm fibras simpáticas pré e pósganglionares. Os ramos comunicantes restantes, contêm apenas fibras viscerais simpáticas pós-ganglionares aferentes. Os ramos comunicantes, correm entre os nervos lombares e o tronco simpático, e, por isso, ficam em 
grande parte debaixo do músculo psoas menor. Eles têm menos de um milímetro de diâmetro e possuem aproximadamente cinco milímetros de comprimento. Os ramos caudais ao quarto ramo lombar, consistem apenas, em ramos cinzentos (fibras pós-ganglionares e fibras aferentes viscerais gerais que voltam para o tronco principal, para ser distribuídas via outros três ramos primários).

Os ramos ventrais dos sete pares de nervos lombares, é variável, mas menos que os ramos dorsais. Eles são, normalmente, descritos como nervos lombares, sem especificamente referir como ramos ventrais. Como o plexo braquial, que dá origem aos nervos que suprem o membro torácico, os últimos cinco nervos lombares e todos os nervos sacrais, são unidos, para formar o plexo lombossacral (plexus lumbosacralis), através do qual os nervos que vão para o membro pélvico se originam. Este plexo pode ser dividido em porções lombar e sacral. Os primeiros dois nervos lombares normalmente não são unidos a um ao outro ou para nervos adjacentes mas correm caudolateralmente na parede abdominal, em série com os últimos nervos torácicos caudais, não incluindo, então, o plexos lombossacral. Os nervos íleo-hipogástrico cranial e caudal representam os ramos primárias ventrais do primeiro e segundo nervos lombares, respectivamente. Ambos os nervos emitem ramos mediais, que são ramos musculares, ao músculo quadrado lombar e psoas menor. Depois de deixar a porção torácica caudal da musculatura hipaxial, passando entre os dois segmentos do músculo quadrado lombar, o nervo íleo-hipogástrico se localiza na fáscia endotorácica de sua origem. Passa, então, através da fáscia subserosa 
transversa do abdome, passando, dorsal ao arco lombocostal. Emite ramos a serosa e aos segmentos do músculo quadrado lombar contrário aos seus ramos. Após ter atravessado a aponeurose de origem do músculo transverso do abdome, corre entre duas lojas musculares adjacentes do transverso abdominal, pois estas lojas musculares surgem de uma aponeurose estreita que as fixa ao final dos processos transversos das vértebras lombares. Logo após entrar na fáscia que separa o músculo transverso do abdome do músculo oblíquo abdominal interno, o nervo íleo-hipogástrico cranial dividese em ramos laterais e mediais.

O ramo lateral, passa através do músculo oblíquo abdominal interno e corre no septo entre os dois músculos oblíquos abdominais. Em seu curso ventro-caudal, envia a maioria de seus ramos a estes músculos, e próximo ao meio do abdômen perfura o músculo oblíquo abdominal externo e se torna subcutâneo, o ramo lateral cutâneo (ramus lateralis cutaneus). É acompanhado por um ramo da artéria e veia abdominal cranial.

O ramo cutâneo lateral é distribuído para percorrer uma faixa ventrolateral de pele, que cruza a junção dos terços médio cranial e medial do abdômen caudalmente às costelas. O ramo medial (ramus medialis) corre junto à superfície lateral do músculo transverso do abdome, onde aparece em série com os últimos cinco nervos torácicos e o segundo e terceiro nervos lombares. Como o ramo lateral, é acompanhado também por um pequeno ramo da artéria e veia abdominal cranial. Supre uma faixa do músculo transverso do abdome e peritônio ao longo de seu curso. Termina dorsalmente, no primeiro segmento lombar do músculo reto do abdome e 
peritônio. O ramo ventral do segundo nervo lombar (o nervo íleohipogástrico caudal) é, em todos os aspectos, semelhante ao primeiro nervo lombar, exceto que nutre a parede abdominal caudal, e aparece na borda lateral da musculatura hipaxial, após ter passado entre o músculo quadrado lombar e o íleopsoas no arco lombocostal. Ocasionalmente, um dos nervos íleo-hipogástrico é duplo, com uma diminuição recíproca em tamanho do nervo caudal a ele. Raramente é um único nervo formado pela fusão do primeiro e segundo, ou, do segundo e terceiro nervos lombares. 0 ramo cutâneo lateral do nervo íleo-hipogástrico caudal, é semelhante ao íleo-hipogástrico cranial, exceto no fato de que, não vai ventralmente tão distante até a linha média ventral. (KITCHELL e EVANS, 1993).

O nervo hipogástrico caudal também não tem nenhum ramo cutâneo ventral (BAILEY et al , 1984).

O plexo lombossacral (plexus lumbosacralis) consiste de ramos intercomunicantes ventrais dos últimos cinco nervos lombares e os três nervos sacros. Pode ser dividido em plexo lombar e plexo sacral, embora os dois sempre têm comunicações. Em geral, os nervos lombares 3, 4, e 5 contribuem para a formação do nervo femoral; $L_{3}$ e $L_{4}$ para o nervo genitofemoral; $L_{4}, L_{5}$ e $L_{6}$ para o nervo obturador; $L_{6}$, $L_{7}$, e $S_{1}$ para o nervo glúteo cranial; $L_{6}, L_{7}, S_{1}$, e $S_{2}$ para o nervo isquiático e seus ramos; e $S_{1}, S_{2}$, e $S_{3}$ para o nervo pudendo. (deLAHUNTA, 1977).

A divisão do plexos lombossacral em seus dois componentes, é feita principalmente, pela sua localização, e não pela sua origem. As conexões entre o terceiro e quarto nervos lombares dão origem ao ramo genito- 
femoral, considerando que a conexão entre o quarto e quinto nervos lombares é normalmente destituída de ramos.

O nervo de íleo-inguinal é a continuação direta da parte principal do ramo primário ventral do terceiro nervo lombar Ele emite ramos mediais que suprem o músculo psoas maior, psoas menor, e ilíaco. O nervo íleo-inguinal se comunica com o quarto nervo lombar e se divide em ramo medial e ramo lateral que se assemelha aos nervos lombares que o precedem . O ramo lateral se estende caudoventralmente e termina como o ramo cutâneo lateral que se ramifica na superfície da pele de craniolateral da coxa. O ramo ,medial do nervo íleo-inguinal é pequeno. Corre mais caudalmente que ventrolateralmente acompanhado por um ramo cranial do ramo ascendente dos vasos ilíacos circunflexos profundos. Não há nenhum ramo cutâneo grotescamente demonstrável e, assim, nenhuma área cutânea. O nervo genito-femoral é chamado nervo espermático externo em muitas publicações veterinárias. No cão, não há um ramo femoral separado, como em humanos, mas, ao invés, tem numerosos ramos que suprem a pele no aspecto proximal da coxa e vários ramos genitais que suprem a pele da região pudenda. O nervo genito-femoral surge do terceiro e quarto nervos lombares, a raiz do terceiro é maior que a raiz do quarto. (KITCHELL e EVANS, 1993).

BAILEY et al, (1984) acharam que o nervo surge de $L_{3}$ e $L_{4}$ em três de quatro cachorros e $L_{2}$ e $L_{3}$ em um de quatro cachorros.

Normalmente o nervo é único, pequeno, e longo. É formado na substância da porção medial do músculo íleopsoas, próximo ao corpo da 
quarta vértebra lombar. Como corre caudalmente, deixa a substância da parte medial do músculo e continua caudalmente no tecido adiposo que preenche as irregularidades ao redor da veia cava caudal e aorta. Depois de passar dorsal ao nódulo linfático ilíaco externo, para o qual envia um pequeno ramo, é relacionado à porção distal da artéria ilíaca externa que cruza medialmente. Deixa o abdômen atravessando o canal inguinal onde corre medial ao cordão espermático, no macho, ou associado ao ligamento largo do útero na fêmea. Ramos musculares minuciosos inervam o músculo cremaster. O nervo femoral surge principalmente do quinto segmento do plexo lombar, com porções consideráveis da origem que também vem do quarto e sexto ramos ventrais. (KITCHELL e EVANS, 1993).

BAILEY et al. (1988) descobriu que o nervo surge de $L_{5}$ e $L_{6}$ em cinco de 11 cachorros; $L_{4}, L_{5}$, e $L_{6}$ em quatro de 11 cachorros; $L_{4}$ e $L_{5}$ em um de 11 cachorros.

O nervo de obturador surge do quarto, quinto, e sexto nervos lombares. A sexta raiz de origem, normalmente é maior, e a quarta menor, ou até mesmo ausente. As raízes de origem não surgem perto do forame intervertebral, mas de grandes troncos do plexo lombar que também contribuem a outros nervos (isquiático para o sexto, e o femoral para o quinto) isto é, as continuações principais do quinto e sexto nervos lombares. O nervo obturador é formado dentro da porção caudomedial do músculo íleopsoas. Deixa este dorsomedialmente e, depois de cruzar ventralmente, acompanhando a veia ilíaca comum, entra no subserosa da pélvis. (KITCHELL e EVANS, 1993). 
Já para a descrição do nervo íleo-hipogástrico cranial, Nervo íleohipogástrico caudal, nervo ílio-inguinal, nervo genito-femoral, nervo obturador, nervo pélvico e nervo isquiático, citam-se as descrições feitas por GOSHAL, em 1975:

- "o nervo íleo-hipogástrico cranial é o ramo ventral do primeiro nervo lombar. O ramo ventral do segundo nervo lombar é o nervo íleo-hipogástrico caudal. Ambos penetram no músculo quadrado lombar e passam sobre a origem aponeurótica do músculo transverso do abdome para obterem entrada na sua parte muscular. O nervo ílio-inguinal, que é a extensão ventrolateral do terceiro nervo lombar, às vezes recebe uma contribuição daquela do segundo nervo lombar, e, anastomosa-se com o quarto nervo lombar. O nervo genito-femoral é essencialmente formado pelos ramos ventrais do terceiro e quarto nervos lombares. O nervo obturador é formado pelo quarto, quinto e sexto nervos lombares. Eles convergem dentro do músculo íleopsoas. Depois segue caudoventralmente, no sentido da abertura pélvica cranial, medial ao corpo do íleo. Ele continua a sua descida ao longo da superfície craniolateral do forame obturador externo, o músculo pectíneo, grácil e adutor.

\subsection{Anestesia local, via espaço peridural em cães}

MAILHAC et al (1980) citam que: "as primeiras experiências com anestesia epidural em cães foram realizadas em 1901 por SICARD e por 
CATHELIN, pela via sacral e que foi CORNING em 1885 que, pela primeira vez, injetou um produto anestésico no canal raquidiano, no espaço subaracnóideo e relata suas observações". BROOK, em 1935 cita que: "CORNING, 1885 em sua pesquisa com a injeção de solução de cocaína entre duas vértebras torácicas em cão, obteve anestesia dos membros pélvicos, pênis, uretra e região inguinal". O mérito da introdução, na prática é de CUILLÉ et SENDRAIL, que em 1901, exploraram a técnica e a compreenderam por inteiro. ANTOINE \& LIÉGEOIS (1931), et BERLUREAU (1933), fizeram uma primeira síntese de trabalhos precedentes. Em 1952, LEGAY considerou a anestesia epidural em cães como muito simples. Cita ainda que, foi MARTIN (1959) quem definiu a anestesia epidural: a anestesia epidural é uma anestesia regional multitroncular realizada na porção epidural do canal raquidiano; ela consiste em embeber de solução anestésica uma certa quantidade de raízes de nervos raquidianos a partir de um ponto de injeção..

Segundo SCHIMIDT et al, 1993: "a anestesia epidural promove completa analgesia e relaxamento muscular da metade posterior do corpo e permite procedimentos cirúrgicos caudais ao diafragma e que, em anestesiologia humana a injeção subaracnóidea diretamente no fluido cerebrospinal (“ anestesia espinhal”) é muito usada, mas em pequenos animais apenas a injeção no espaço epidural é utilizada".

JONES, 2001, cita que: "as indicações promovem anestesia e analgesia para alguns procedimentos cirúrgicos ortopédicos em ossos longos e cesarianas". 
QUANDT e RAWLINGS, 1996, citam como principais indicações da anestesia epidural: "as cirurgias nos membros pélvicos, coxal, região anal, perianal e caudal, mas que ela pode ser também utilizada em cirurgias abdominais".

A anestesia epidural resulta bloqueio sensorial, motor e autonômico. Os efeitos autonômicos devem ser significantes se o bloqueio se estender à região torácica e interromper fibras nervosas simpáticas. Bradicardia pode também ocorrer como resultado de bloqueio de fibras nervosas cardioaceleradoras se a anestesia epidural se estender cranialmente às primeiras quatro vértebras torácicas. A função respiratória não é diminuída a não ser que os anestésicos locais produzam bloqueio motor do nervo frênico em $\mathrm{C}_{3}$ a $\mathrm{C}_{5}$. (TORSKE e DYSON - 2000)

Segundo HASKINS, 1992, a técnica epidural: "promove analgesia ou anestesia apenas para a porção caudal do corpo; o movimento da parte cranial pode ser um problema".

SWALANDER et al, 2000, conclui que: "a taxa de complicações associadas com a cateterização epidural em cães parecem ser baixas e, geralmente não são de relevância clínica”.

HEATH (1992) conclui que: "as técnicas espinhais (injeção epidural e subaracnóidea) são ensinadas nas escolas de veterinária, mas, por serem menos convenientes não são amplamente utilizadas na rotina prática. Muitos animais submetidos à rotina cirúrgica (i.e. atos até nível umbilical) podem ser anestesiados com sedação leve e analgesia epidural caudal". 
SCHIMIDT et al (1993) cita que as vantagens do bloqueio epidural são: "a falta de depressão central; funções cardiorrespiratórias mantidas inalteradas enquanto que, a analgesia e relaxamento muscular são totais. Isto a torna particularmente adequada para pacientes de alto risco". E cita como desvantagens: "diminuição do reflexo periférico de vasoconstrição resultado do bloqueio autonômico na região anestesiada e o conseqüente perigo de hipotensão após perda sanguínea". Entretanto, diz ainda que: "ao contrário dos humanos, uma pesada sedação é sempre necessária em cães e gatos. Eles não toleram o decúbito na mesa cirúrgica por longos períodos sem sofrer estresse. Portanto, a pré-medicação sedativa restringe consideravelmente as vantagens da técnica epidural".

A anestesia epidural, assim como outras anestesias regionais, tem sido erroneamente considerada uma anestesia livre de efeitos deletérios e complicações, sendo, dessa forma, indicada para pacientes de risco. Entretanto seus efeitos cardiovasculares facilmente compensados em paciente hígido podem ser irreversíveis em paciente com alterações. Dessa forma é necessária uma avaliação cuidadosa do quadro clínico antes de se optar pela anestesia epidural. (INTELIZANO et al, 2002).

Anestésicos locais e analgésicos podem ser administrados através de cateter $(0,8 \mathrm{~mm})$ que têm sido inseridos via espaço lombosacral no espaço epidural entre a quarta e a sexta vértebra lombar e, ancorado seguramente na pele. Os cateteres podem permanecer nesta posição até cinco dias sem efeitos deletérios. (BONATH et al, 1984). 
Já, MASSONE (1999) cita que: "a anestesia peridural (epidural), é uma anestesia regional, segmentar, temporária, produzido por fármacos anestésicos em diferentes concentrações e doses e depositadas no canal espinhal. E, quanto a seu modo de ação: "inicialmente, através do espaço epidural, são atingidos os nervos espinhais que passarão pelo forames intervertebrais, obtendo-se um bloqueio paravertebral múltiplo; segue-se dentro do espaço epidural, o bloqueio dos ramos nervosos e gânglios; difusão na dura-máter, que poderá causar, quando houver deposição excessiva de anestésico, uma anestesia subaracnóidea retardada; e difusão e absorção seletiva nos ramos ventrais e dorsais, região de drenagem linfática ativa”.

KLIDE, 1992 conclui que: "se deve levar em conta o tipo e a duração do procedimento cirúrgico e o grau de analgesia requerida no pósoperatório, para a escolha dos diferentes anestésicos locais e suas doses e cita: lidocaína a 2\%; Morfina; Bupivacaína a 0,5\%; medetomidina; quetamina; butorfanol; e a xilazina associada à morfina".

HEATH, 1992, conclui em seu artigo que: "a analgesia epidural lombossacral usando lidocaína, mepivacaina e bupivacaína em pacientes que serão submetidos a intervenções cirúrgicas, pode ser uma técnica simples e comum, aceita pela maioria das equipes cirúrgicas e tolerada com sucesso pelo paciente, embora este fato não seja comum na literatura".

A anestesia/analgesia epidural possui efeitos sistêmicos mínimos e é uma técnica útil para o alívio da dor em pacientes críticos. Antes da sua administração o paciente deve ser avaliado apuradamente para identificar 
alguma condição preexistente que impeça o uso da técnica com segurança. Analgesia/anestesia pode ser alcançada através da administração de anestésicos locais, opióides, alfa 2 agonistas, ou a associação destes. Complicações da técnica epidural não são freqüentes e incluem problemas iatrogênicos e idiopáticos, e a maioria delas não tem seqüelas permanentes. (WETMORE et al, 2000)

Em cães, MASSONE, 1999, aconselha: "inicialmente, deve-se recordar a anatomia da coluna vertebral, cuja fórmula é $C_{7}, T_{13}, L_{7}, S_{3}$, C 20-22", e que, em cães "os pontos eletivos para a anestesia epidural são entre $L_{7}$ e $S_{1}$ ou lombossacra e $S_{3}$ e $C_{1}$ ou sacrococcígea ou intercoccígea" Diz ainda que, a anestesia permite executar em período hábil de 60 a 80 minutos, intervenções retro-umbilicais, não permitindo trações viscerais altas, como no caso de cesarianas e ovário-histerectomias, cirurgias estas que implicariam em manipulação e tração dos ligamentos suspensor e uterovárico. Cita ainda que, este fato vale para cirurgias intestinais, pois a manipulação é suave e indolor, mas sua simples tração torna a intervenção cruenta, requerendo anestesia geral. 


\section{MATERIAL E MÉTODO}

Foram utilizados 10 cães anestesiados pelo pentobarbital sódico na dose de $30 \mathrm{mg} / \mathrm{kg}^{1}$, provindos do final da aula prática de técnica cirúrgica da Faculdade de Medicina Veterinária das Faculdades Integradas da Fundação de Ensino Octávio Bastos (FIFEOB) em São João da Boa Vista, estado de São Paulo. Os animais selecionados eram machos ou fêmeas pesando entre oito e 15 quilos.

Estes animais foram tratados com uma sobredose de pentobarbital sódico na dose de $70 \mathrm{mg} / \mathrm{kg}^{1}$ até que se constatou o choque bulbar. Nove destes animais foram então, envolvidos em embalagem plástica, e submetidos ao congelamento rápido em decúbito lateral mantendo a coluna dorsal reta.. Em um dos animais efetuou-se a lavagem do circuito vascular com solução fisiológica ligeiramente aquecida (aproximadamente $38^{\circ} \mathrm{C}$, e infusão de formol a 10\%, infundindo-se seqüencialmente, látex $650^{2}$ colorido em vermelho através da carótida cervical, e látex $650^{3}$ colorido em azul através da veia jugular, com o intuito de se atingir as artérias e veias que, normalmente acompanhavam as inervações, usando-as, assim como ponto referencial para a dissecação e identificação das estruturas desejadas. Este animal, foi então imerso em formol a 10\%, por três dias, e, após esse período, submetido a congelamento, nos mesmos moldes dos nove animais citados anteriormente.

\footnotetext{
${ }^{1}$ Hypnol - Cristália Produtos Químicos e Farmacêuticos

2 látex 600 - Látex do Brasil.........
} 
Em todos os animais, foi feita a secção em plano transversal, entre $T_{12}$ e $T_{13}$, seguida de secção em plano mediano, através da coluna vertebral lombar e sacral, dividindo-os em duas metades iguais. (Fig. 1).

Após o descongelamento da peça, efetuava-se a dissecação das raízes dorsais e ventrais, seus respectivos troncos espinhais, bem como seus ramos anteriores e posteriores, em $L_{1}, L_{3}$ e $L_{6}$, buscando-se evidenciar os principais troncos nervosos até a sua terceira ramificação. 


\section{RESULTADOS}

Os resultados obtidos com a dissecação seriada das inervações lombares dos segmentos $L_{1}, L_{3}$ e $L_{6}$ podem ser observados a partir da Figura 1 onde se nota que a peça havia sido fixada em formol a 10\%, injetada com látex 600 e congelada, para posteriormente ser seccionada de acordo com a metodologia preconizada.

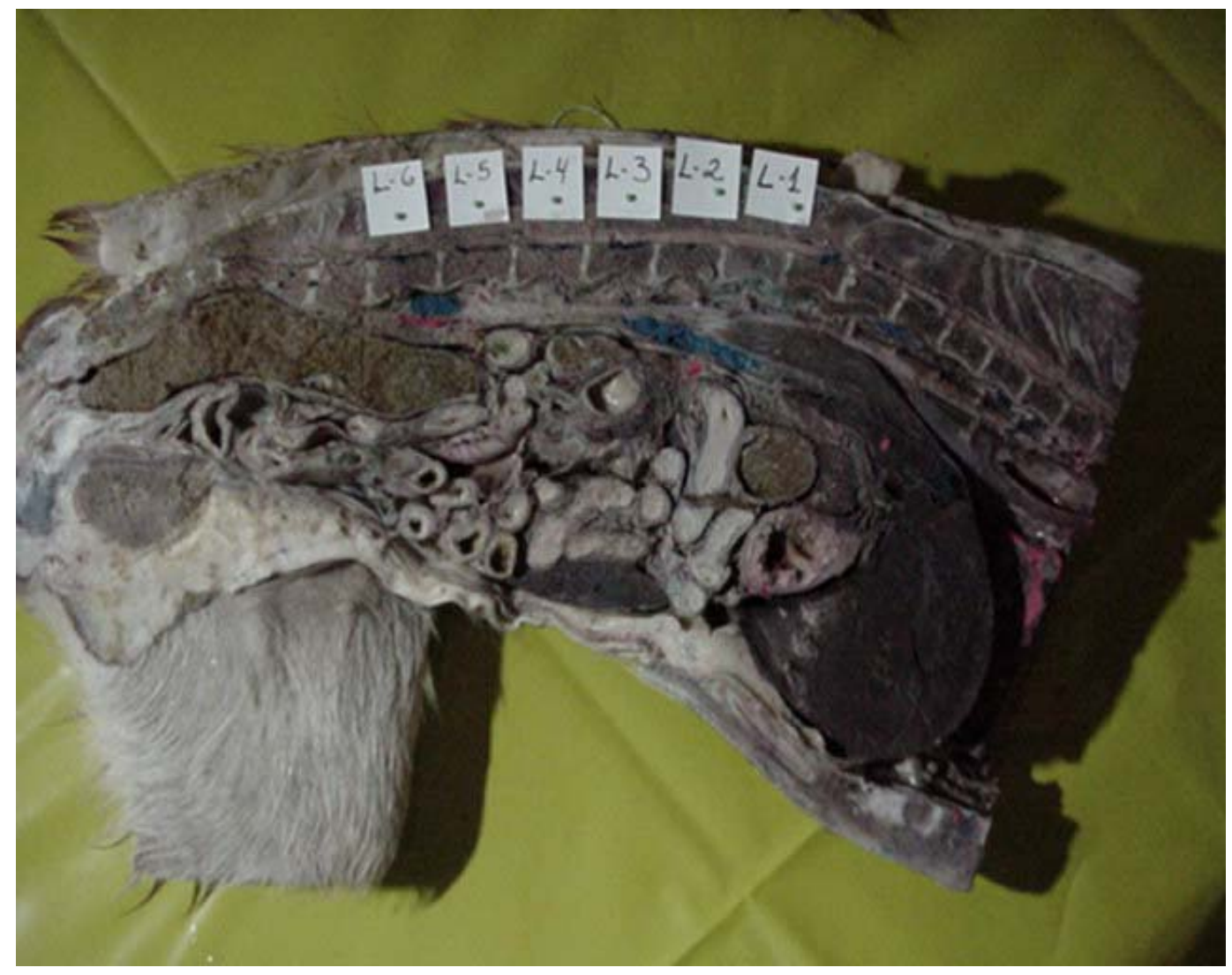

Figura 1 - Peça anatômica , previamente preparada, pronta para o início da dissecação 
A distribuição nervosa dos ramos espinhais de $L_{1}, L_{3}$ e $L_{6}$ podem ser melhor evidenciados no organograma na figura 2.

A partir da dissecação na região de $L_{1}$ observou-se: - saída direta do nervo esplâncnico menor, para formar o tronco esplâncnico lombar do sistema nervoso autônomo, que através do plexo mesentérico cranial, supre intestinos delgado e grosso e ceco; e através do plexo aórtico (intermesentérico) supre gânglio mesentérico caudal e plexo pélvico; como se observa nas figuras 3, 4 e 21; - inervação do gânglio celíaco mesentérico cranial direito, que através do plexo hepático supre pâncreas, duodeno, estômago, ducto cístico, fígado, ducto biliar; - inervação do plexo esplênico que, através do gânglio celíaco esquerdo, supre baço, pâncreas e curvatura maior do estômago; - inervação da cadeia ganglionar celíaca que, através do plexo gástrico esquerdo supre a curvatura menor região do cárdia e fúndica gástricas; e através do plexo mesentérico cranial, passando pelo gânglio mesentérico cranial, supre intestinos delgado e grosso e ceco; - inervação da cadeia ganglionar adrenal, que, através do plexo frênico abdominal, supre o diafragma e parte do peritônio abdominal (fig. 5); e, através do plexo adrenal supre a glândula adrenal;- inervação da cadeia ganglionar aórticorenal e renal, que, através do plexo renal, supre os rins; - inervação do plexo aórtico que, gânglio gonadal e nervo esplâncnico lombar, que, nos machos, através do plexo espermático interno supre testículos e epidídimo; e, nas fêmeas, através do plexo útero-ovariano supre ovários, ovidutos e útero (figs.11 e 21; e, ainda, através do plexo mesentérico caudal supre nervos 
hipogástricos, cólon distal esquerdo, reto e plexo pélvico (figs. 3,4,5 e 21; saída do nervo íleo-hipogástrico cranial. (Figs. 12, 13 e 17).

Já a partir de $L_{3}$ o que se observou foi: - saída direta de nervo esplâncnico menor, para formar o tronco esplâncnico caudal do sistema nervoso autônomo, que através do plexo mesentérico caudal supre nervos hipogástricos, cólon distal esquerdo, reto e plexo pélvico; - saída do nervo íleo-hipogástrico caudal; - saída do nervo íleo-inguinal (figs. 12, 13, 17 e 18); - saída direta de nervo esplâncnico menor, para formar o tronco esplâncnico do sistema nervoso autônomo. (Figs. 6 e 21).

Em $L_{6}$ o que se observou foi: - saída de inervação originando nervo femoral e nervo obturador (figs. 12, 13, 14, 15, 16, 18, 19 e 20); - saída direta de nervo esplâncnico menor, para formar o tronco esplâncnico do sistema nervoso autônomo. (figs. 8 e 21).

Foi encontrado ainda que todas as fibras nervosas se apresentam emergindo de suas raízes ventrais correspondentes para atingir e travar sinapses em tecidos alvo e glândulas abdominais. (Figs. 9 e 10). 


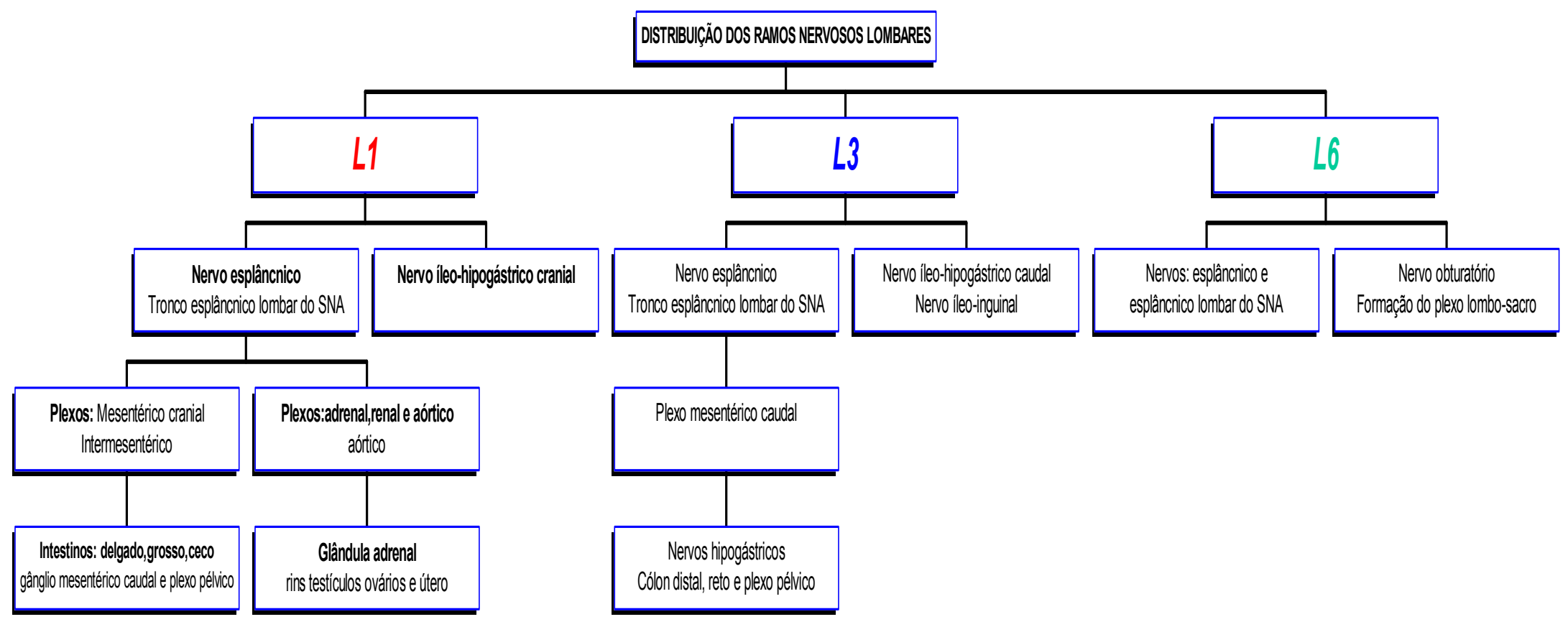

Figura 2 - Distribuição dos ramos nervosos lombares, desde suas raízes nervosas, até seus respectivos tecidos alvo. 


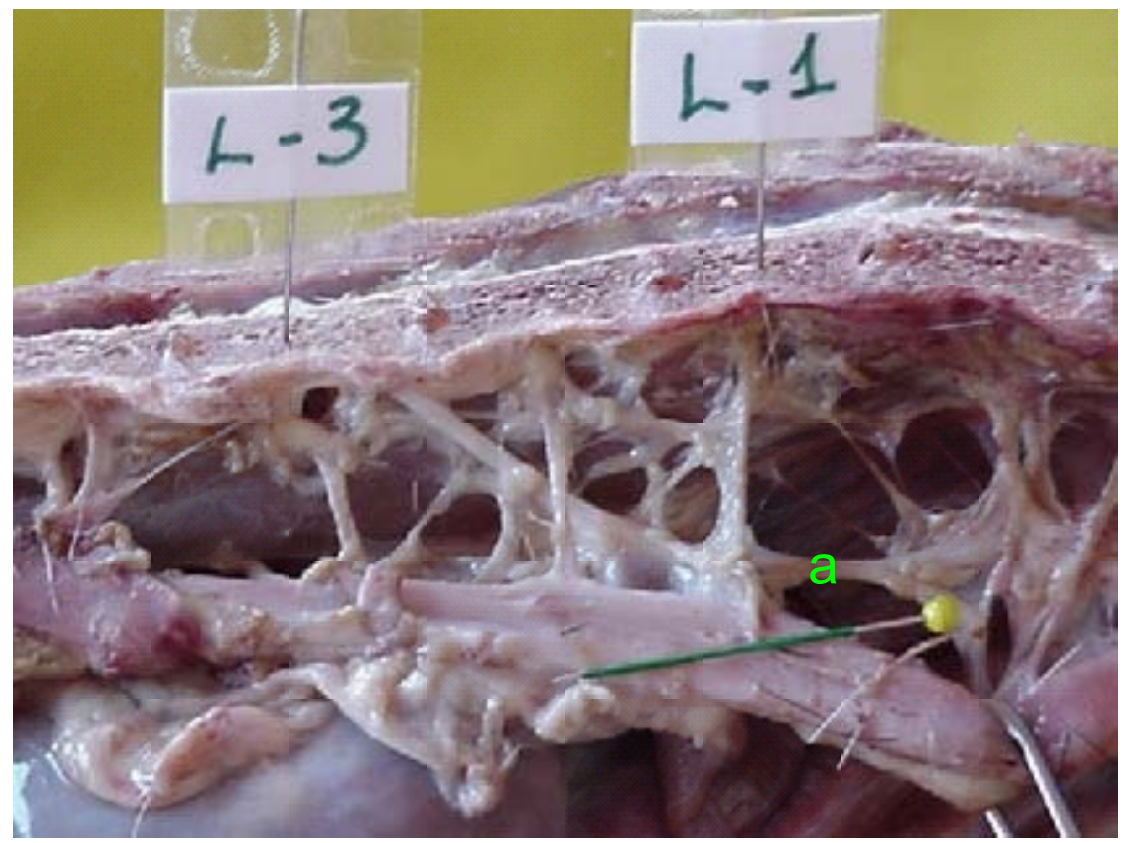

Figura 3 - Nervo esplâncnico maior $(A)$, que se insinua na cavidade abdominal saindo do segmento lombar $\mathrm{T}_{13}$

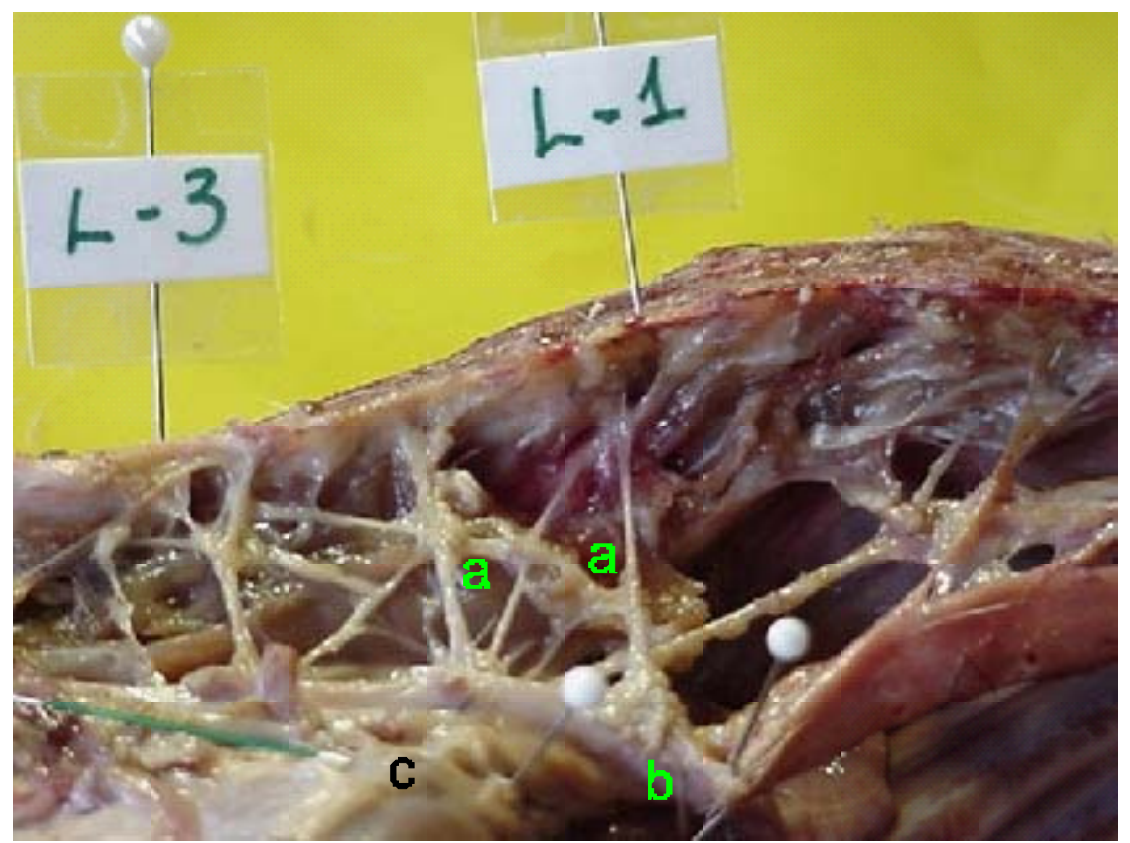

Figura 4 - Nervos esplâncnicos menores (a) emergindo caudalmente ao nervo esplâncnico (A), e suprindo aorta (B) e plexo celíaco-mesentérico $(\mathrm{C})$ 


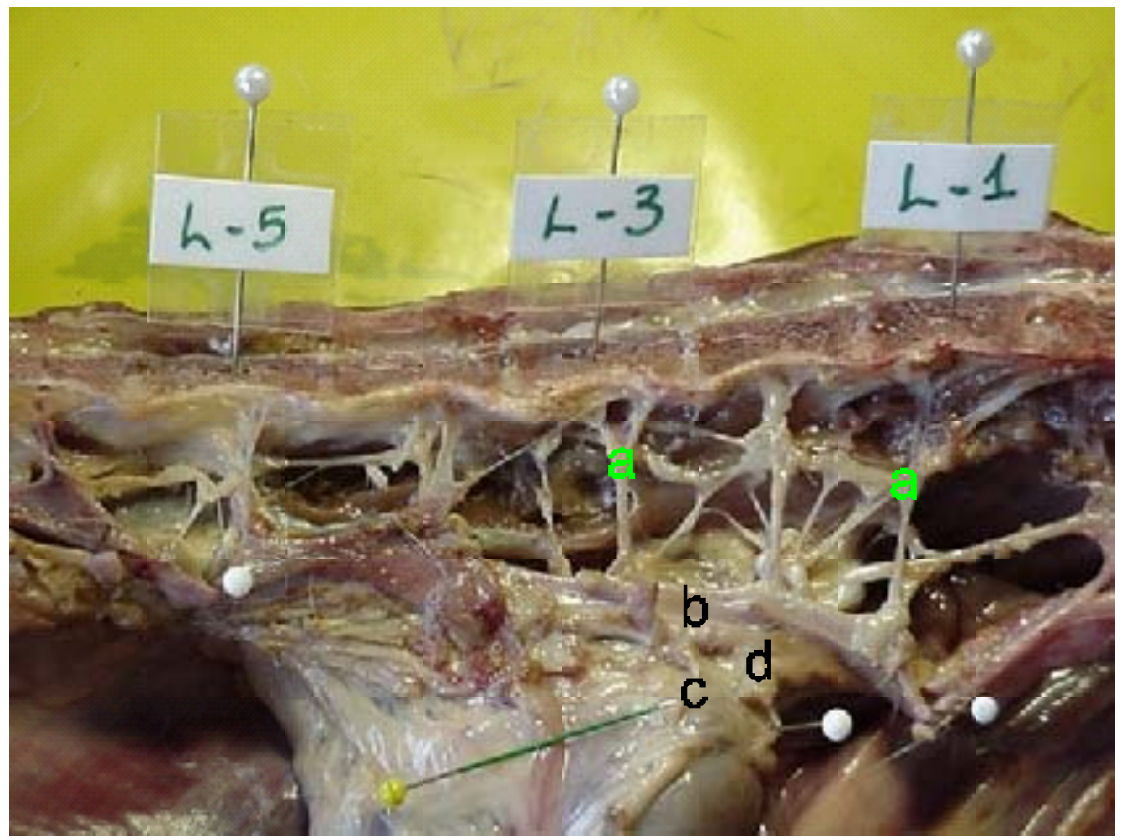

Figura 5 - Nervos esplâncnico lombares(A), saindo de $L_{1}$ e $L_{3}$, deixando tronco simpático caudalmente ao nervo esplâncnico maior, e emitindo filamentos para a aorta(B), glândula adrenal(C) e plexo celíaco mesentérico(D)

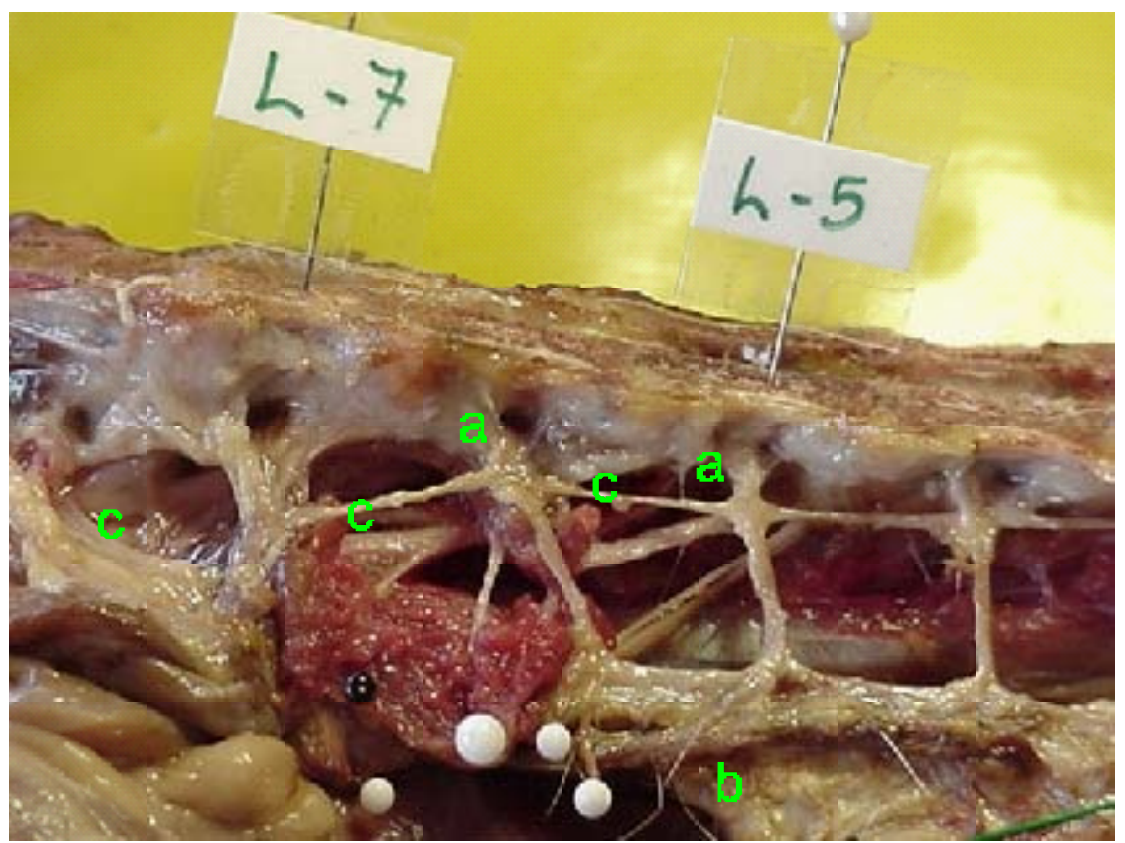

Figura 6 - Quinto e sexto nervos esplâncnicos lombares(A) dirigindo-se diretamente para o plexo mesentérico caudal(B) e emitindo ramos para os nervos hipogástricos (C) 


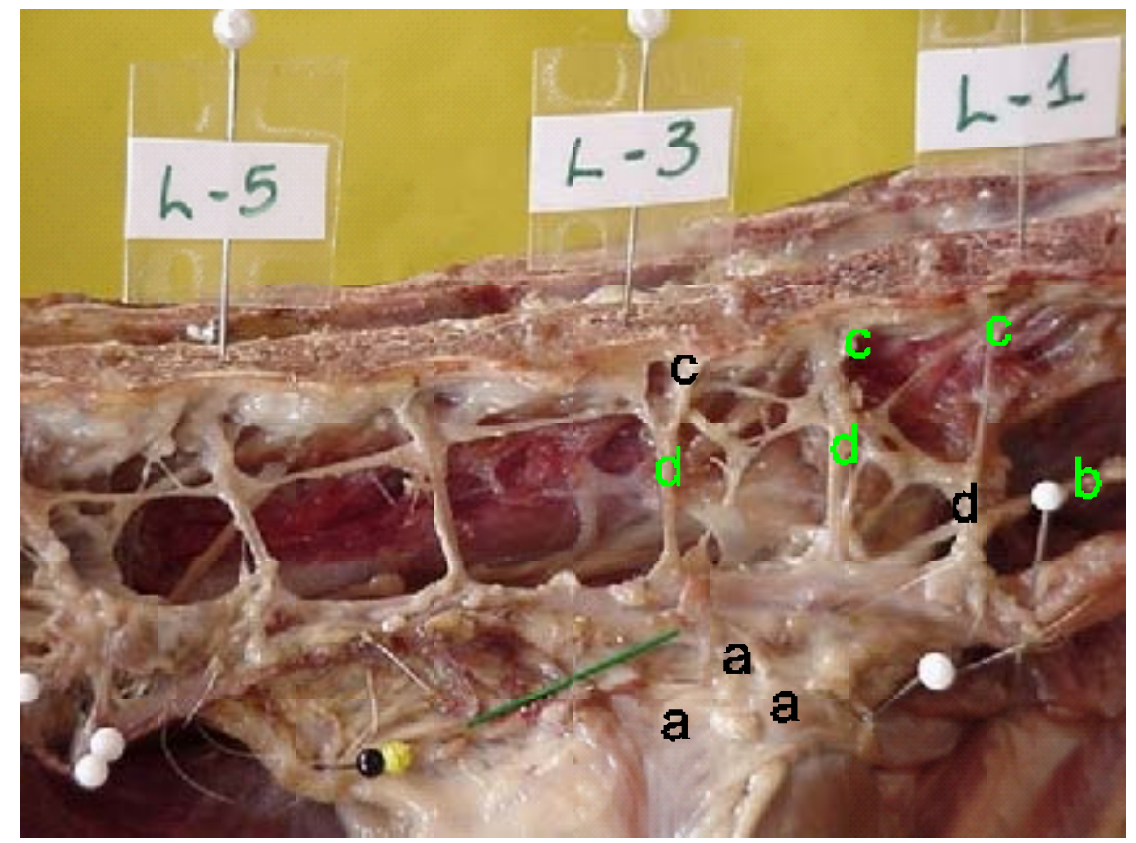

Figura 7 - Aspecto morfológico macroscópico do plexo adrenal, plexo celíaco mesentérico(A) recebendo contribuição das fibras dos nervos espâncnico maior(B) nervos esplâncnicos menores $(C)$ e dos três primeiros nervos esplâncnicos lombares(D)

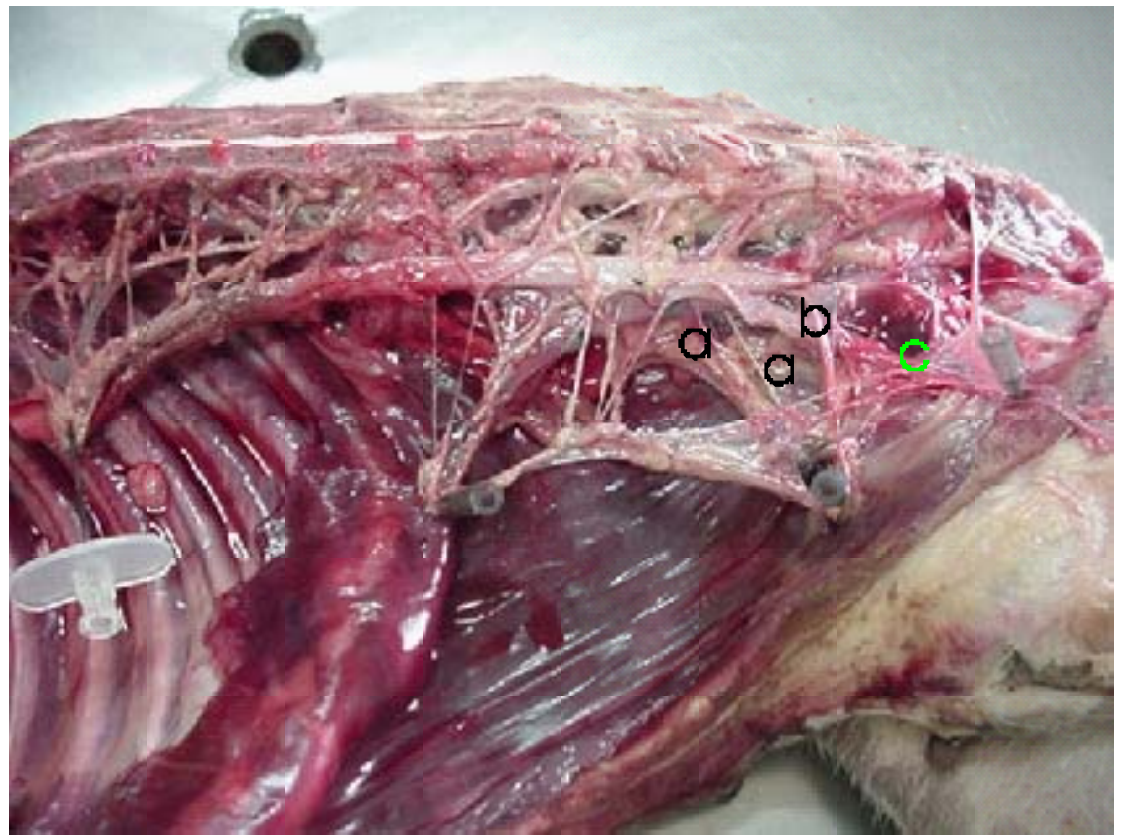

Figura 8 - Aspecto morfológico do plexo mesentérico caudal(A) se originando da artéria mesentérica caudal(B) e ligando-se ao plexo pélvico(C) 


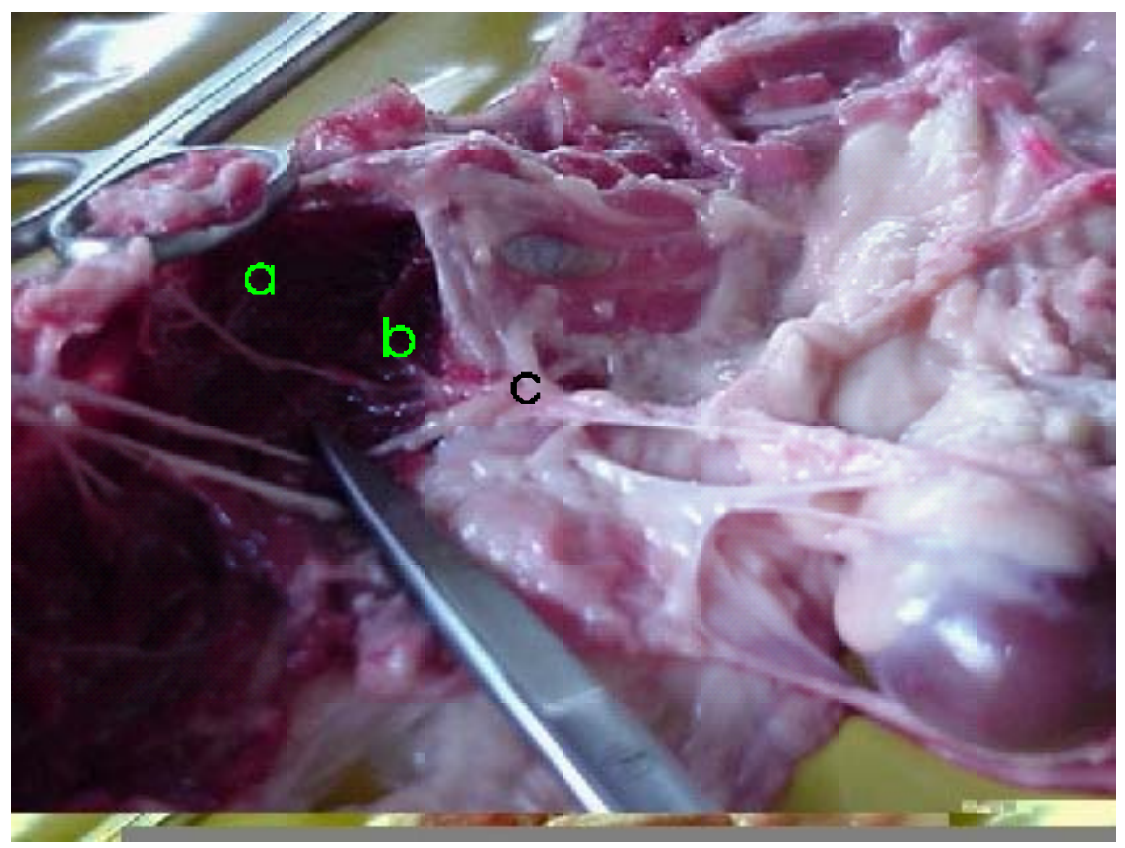

Figura 9 - Fibras nervosas emergindo de suas raízes ventrais(A) atingindo e travando sinapses em tecidos alvo(B) e glândulas abdominais $(\mathrm{C})$

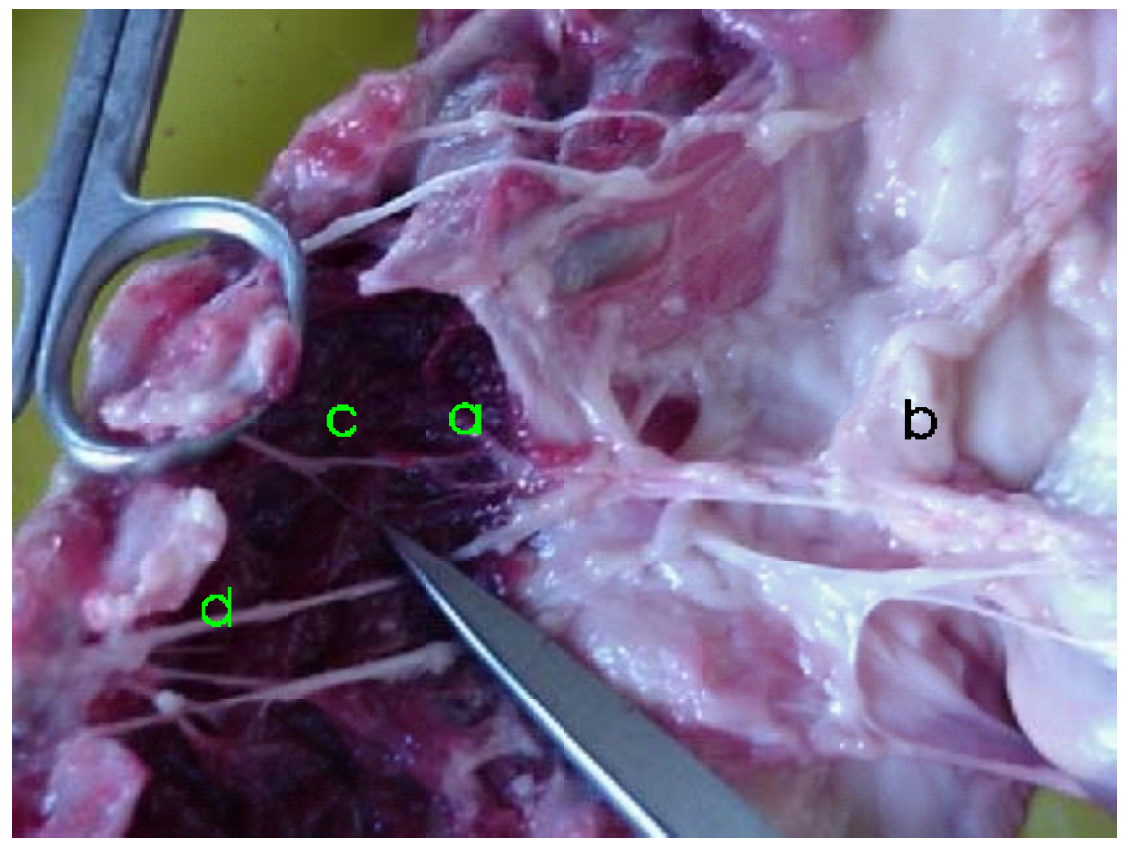

Figura 10 - Fibras nervosas emergindo de suas raízes ventrais atingindo e travando sinapses em tecidos alvo(A) e glândulas abdominais $(B)$,destacando-se os ramos laterais $\odot$ e mediais $(C)$ 


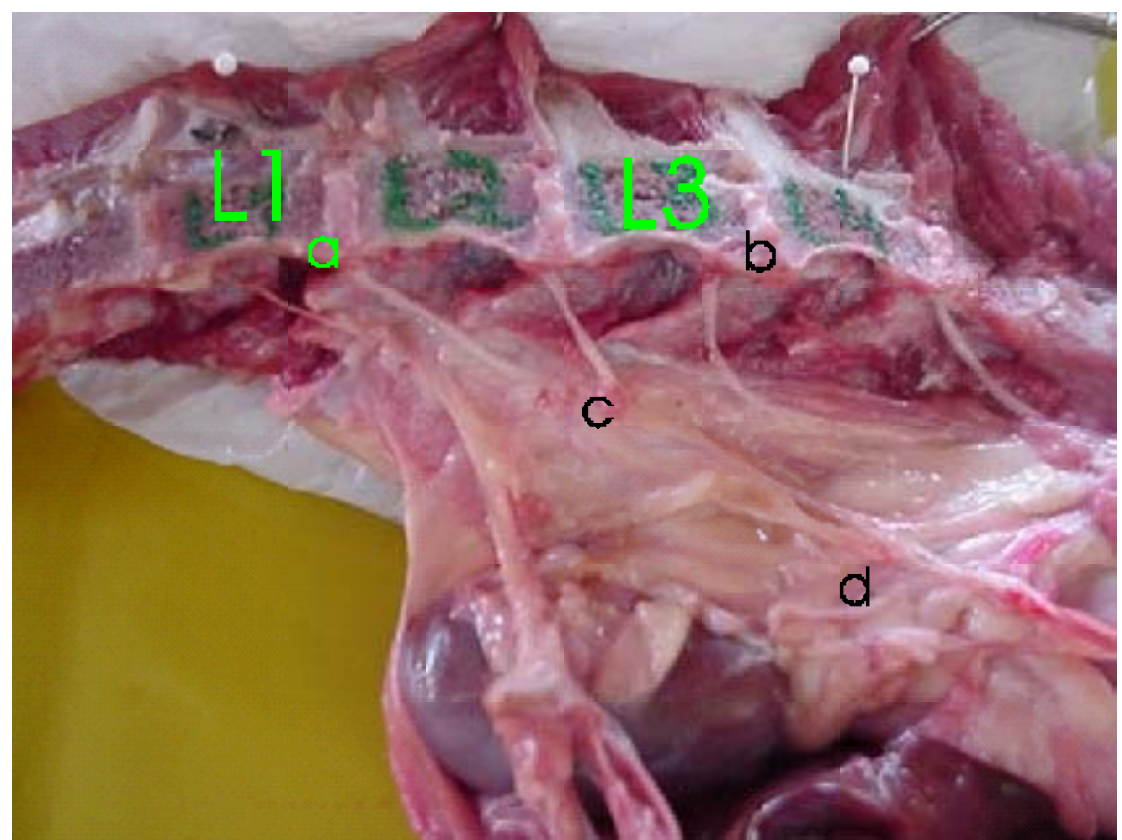

Figura 11 - Fibras nervosas emergentes de $L_{1}(A)$ e $L_{3}(B)$ se insinuando entre os ligamentos abdominais $(C)$, destacando-se os ligamentos ovarianos e uterinos em uma fêmea(D)

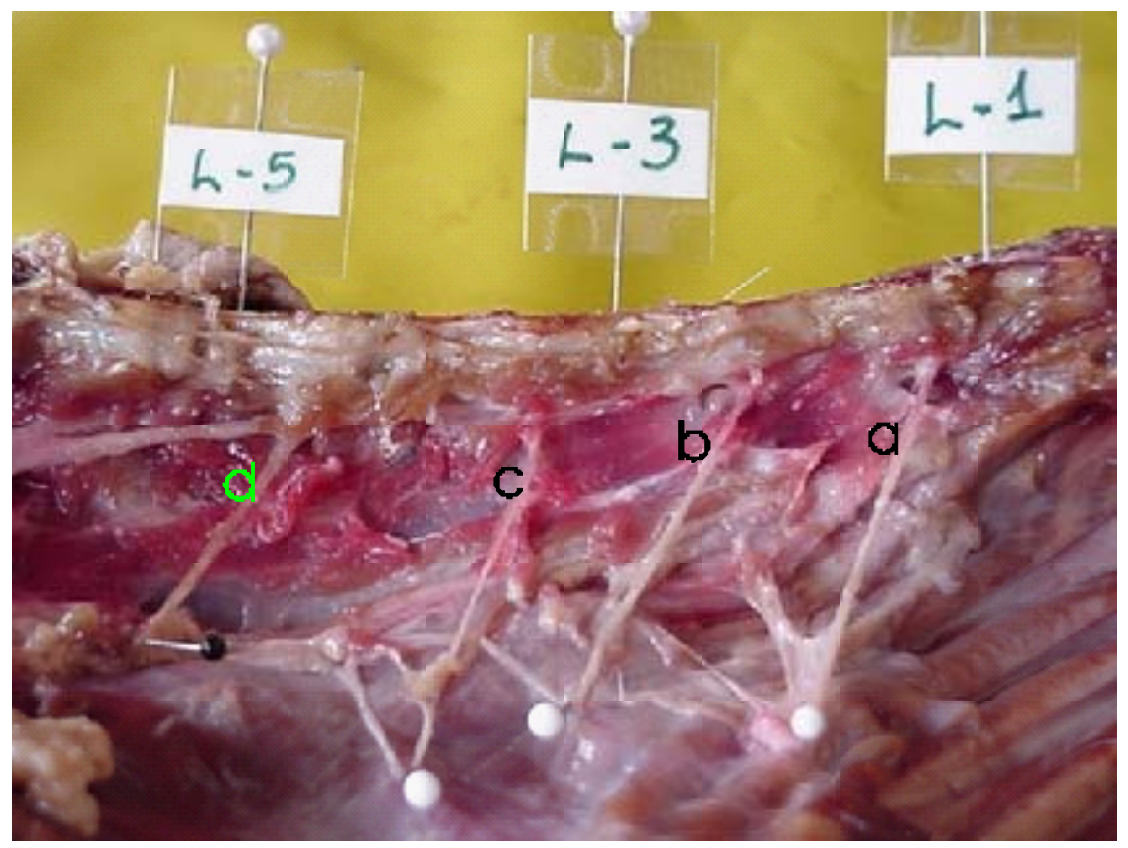

Figura 12 -Aspecto geral dos nervos espinhais lombares, destacando-se nervo íleo-hipogástrico cranial(A), íleo-hipogástrico caudal(B), íleo-inguinal(C) e femoral cutâneo lateral(D) 


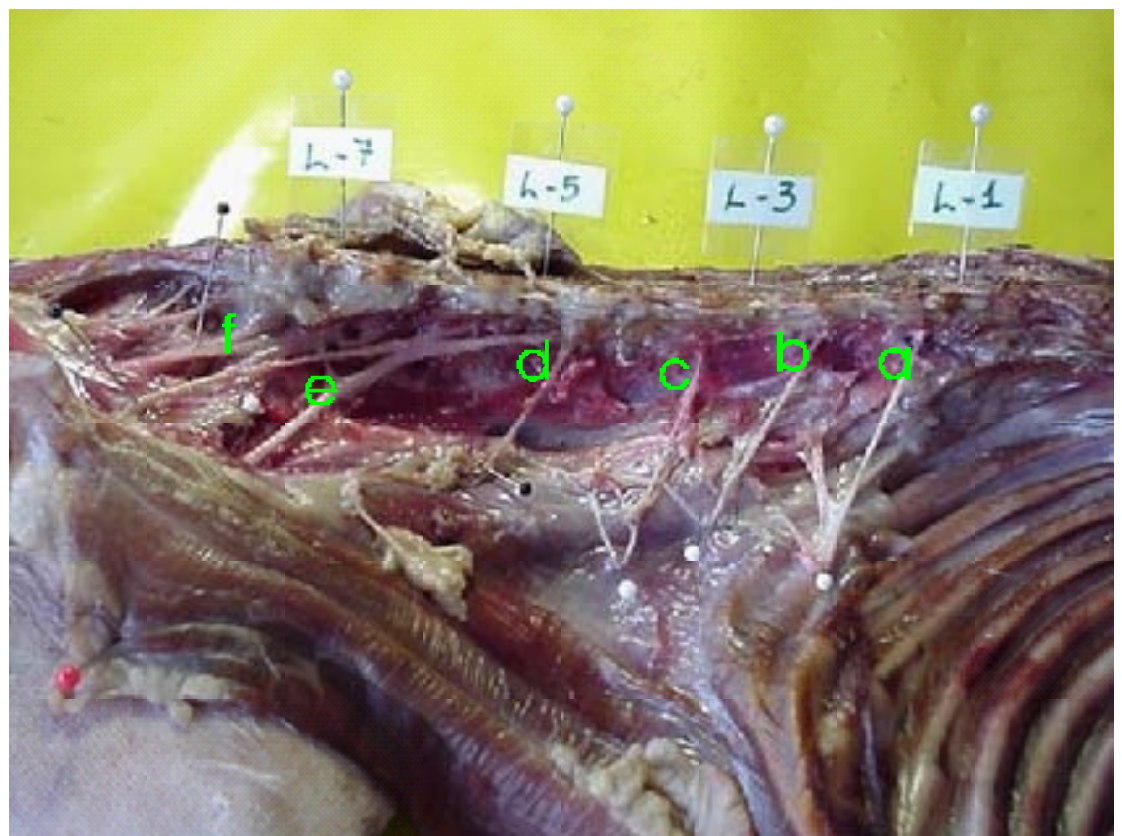

Figura 13 - Aspecto geral dos nervos espinhais lombares destacando-se nervo íleo-hipogástrico cranial(A), íleo-hipogástrico caudal(B), íleo-inguinal(C), cutâneo femoral lateral(D), femoral(E) e obturador $(F)$

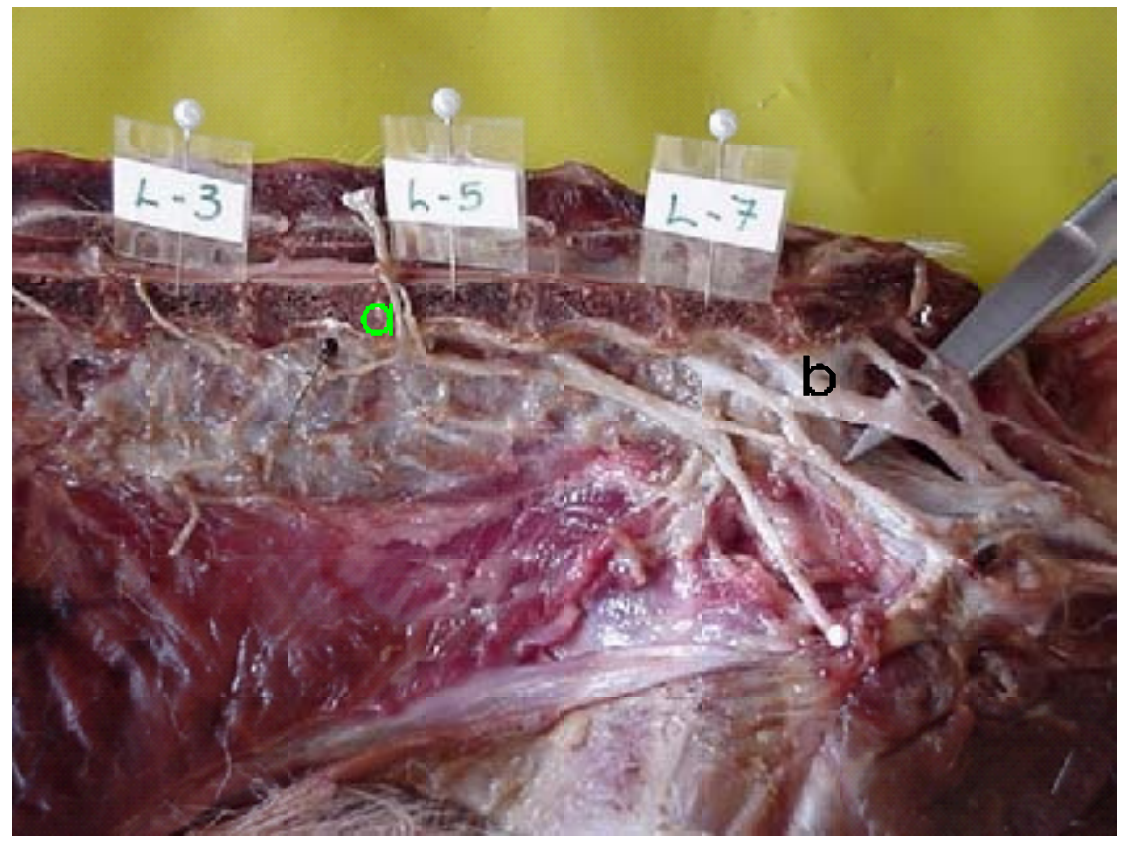

Figura 14 - Últimos nervos esplâncnicos lombares(A) se unindo ao plexo lombar(B) 


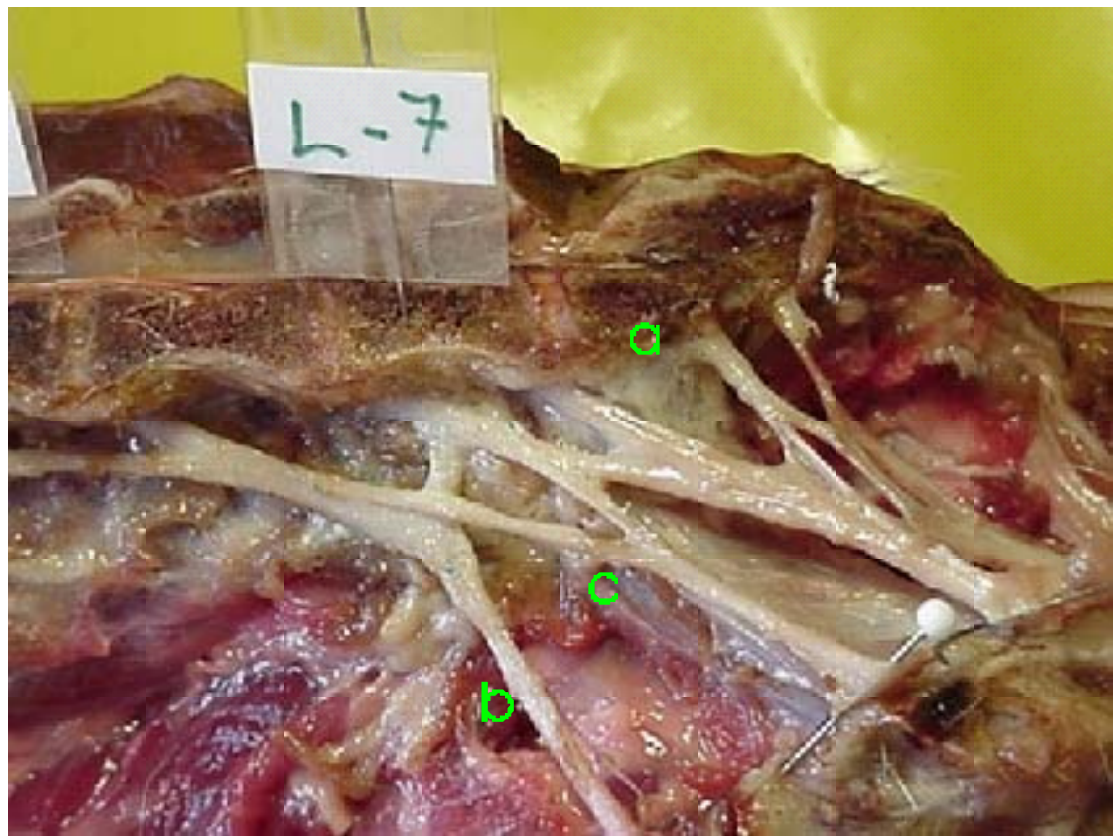

Figura 15 - Plexo lombar(A). nervo femoral(B), nervo obturador(C)

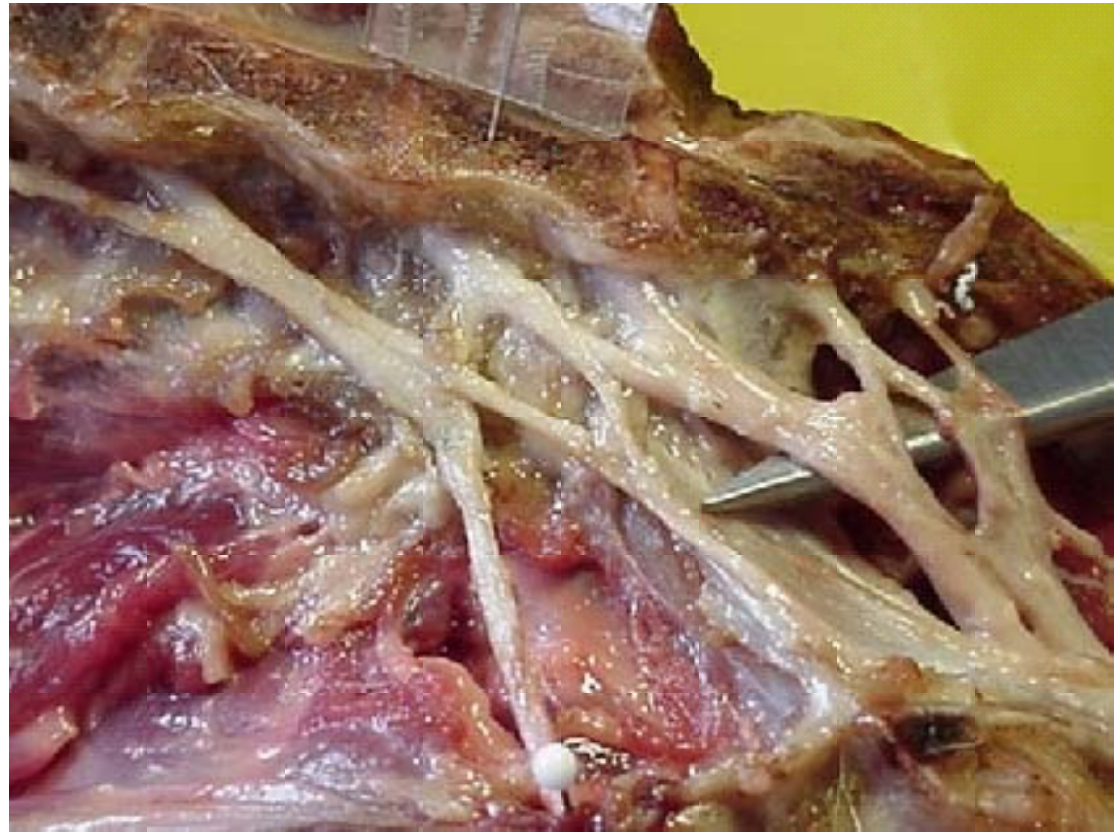

Figura 16 - Plexo lombar vista aproximada 


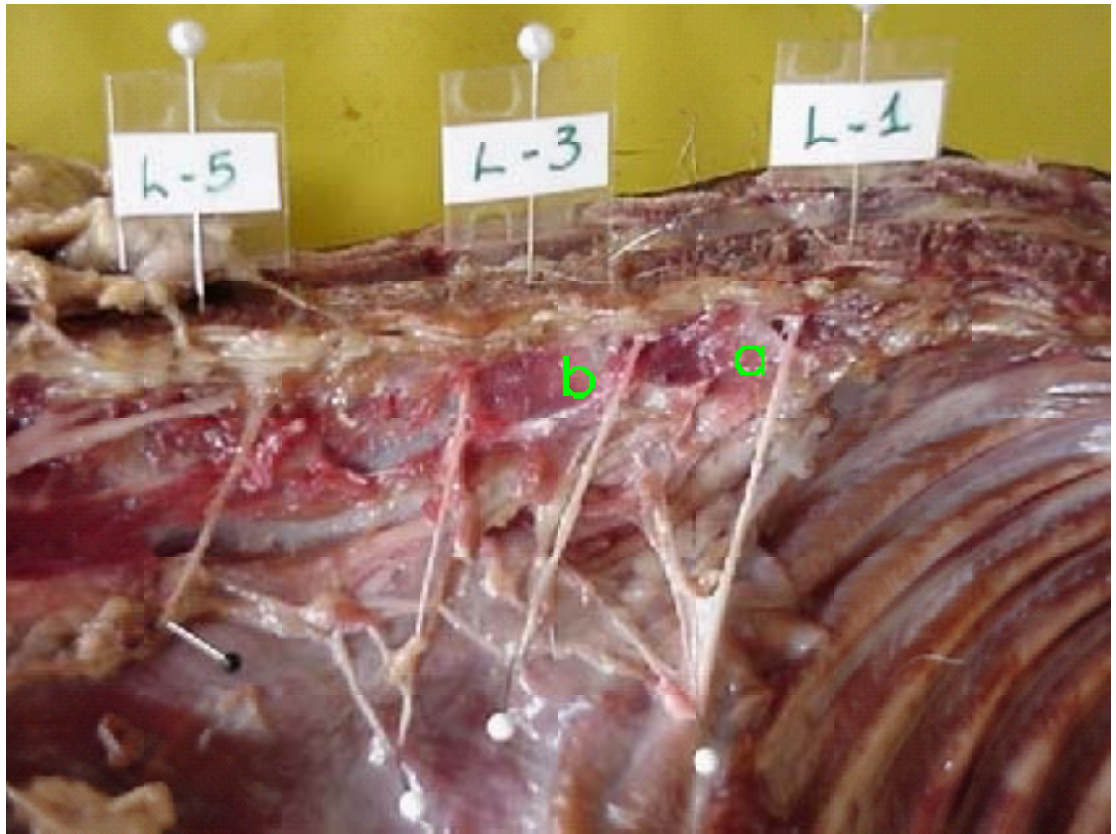

Figura 17 - Saída do nervo íleo-hipogástrico cranial de $L_{1}(A)$, nervo íleo-hipogástrico caudal de $\mathrm{L}_{3}(B)$ formando os dois primeiros pares de nervos lombares.

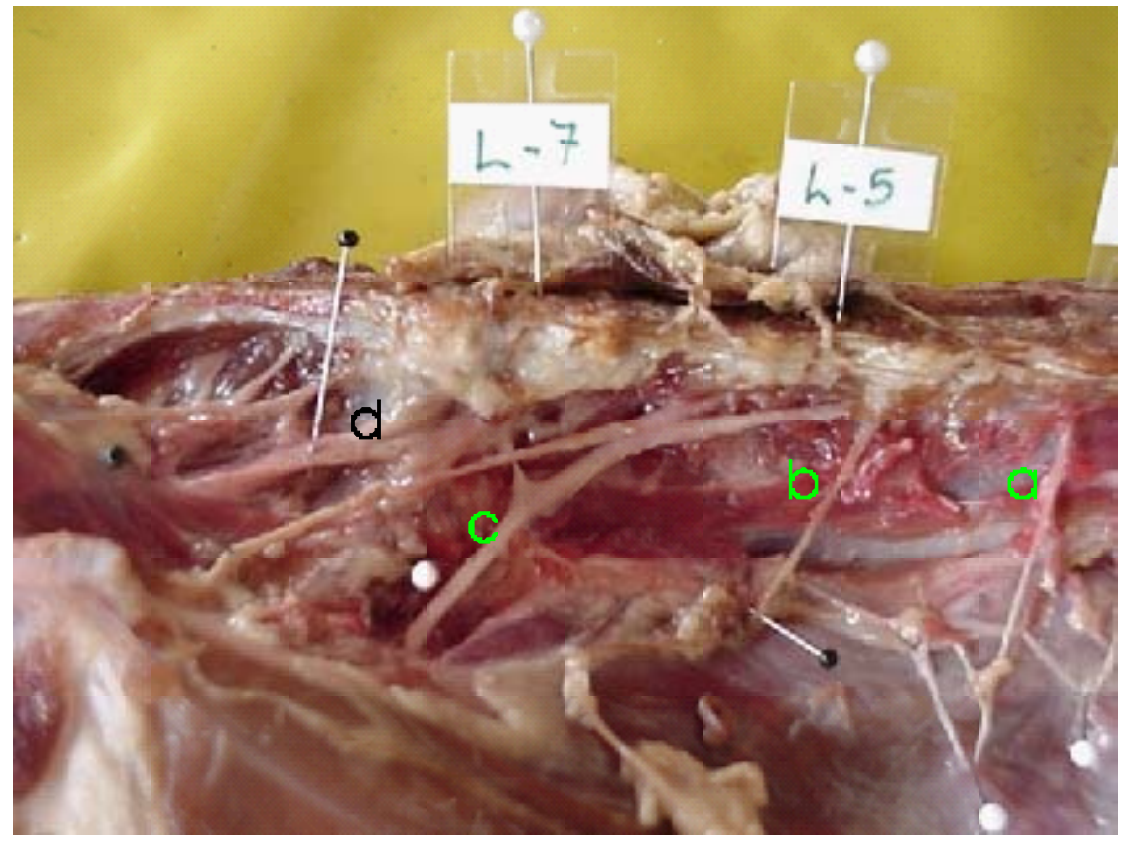

Figura 18 - Nervo íleo-inguinal emergindo em $L_{3}(A)$, nervo femoral cutâneo lateral emergindo em $L_{5}$ (B) nervo femoral entre $L_{5}$ e $L_{6}(C)$ e obturador em $L_{6}$ (D) 


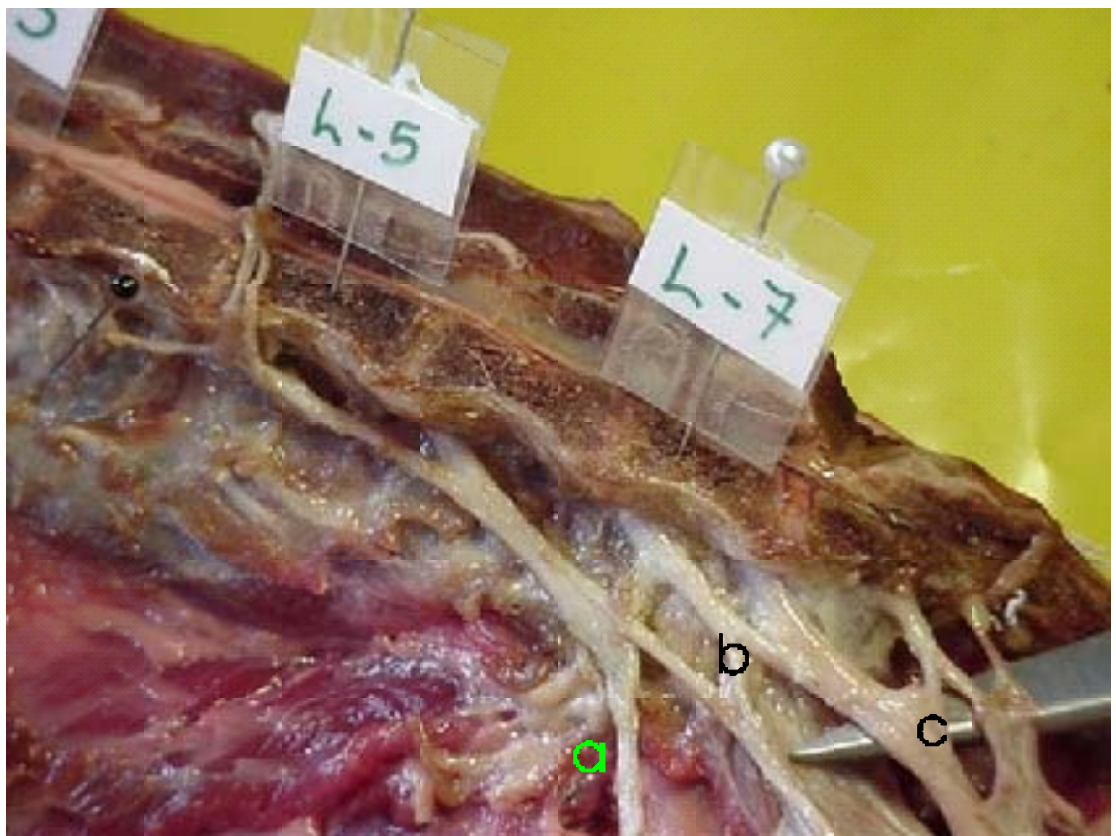

Figura 19 - Nervo femoral saindo de $L_{5}-L_{6}(A)$, nervo obturador de $L_{6}-L_{7}(B)$; nervo isquiático de $L_{7}-S_{1}(C)$

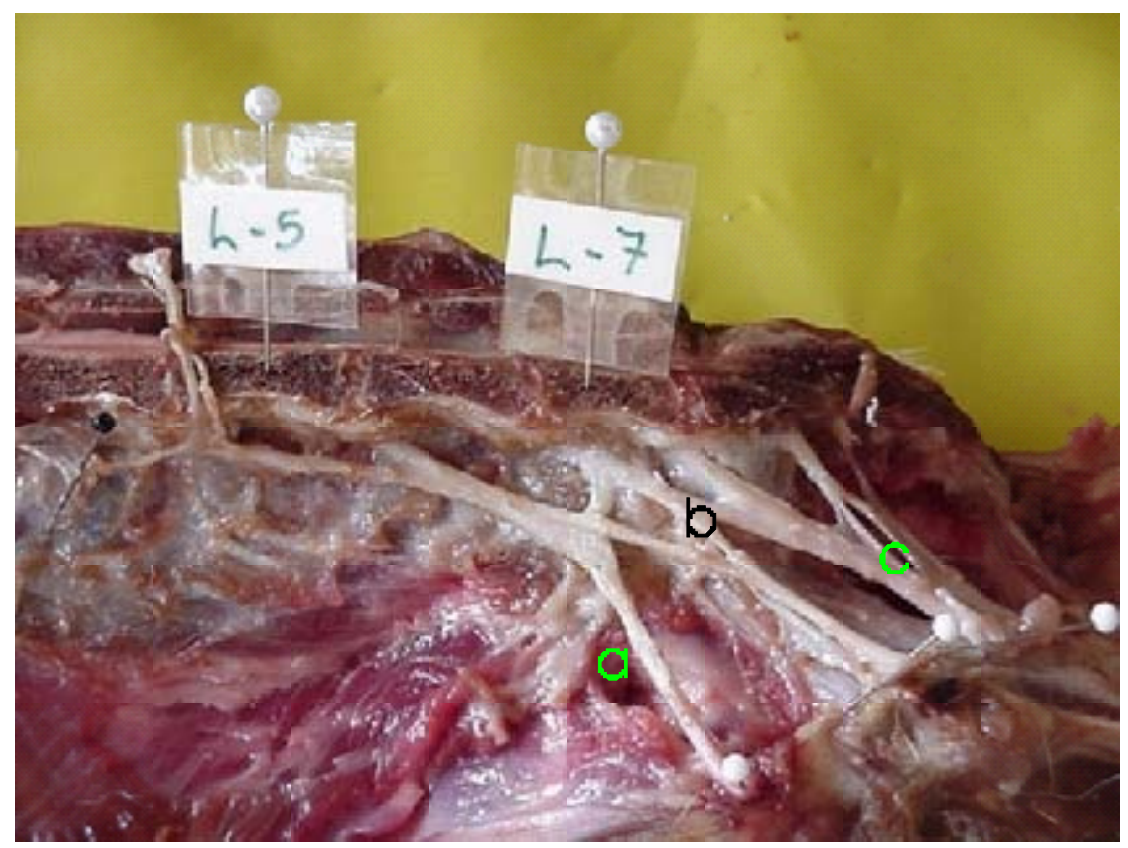

Figura 20 - Nervo femoral saindo de $L_{5}-L_{6}$, (A) nervo obturador de $L_{6}-L_{7}(B)$; nervo isquiático de $L_{7}-S_{1}(C)$ 


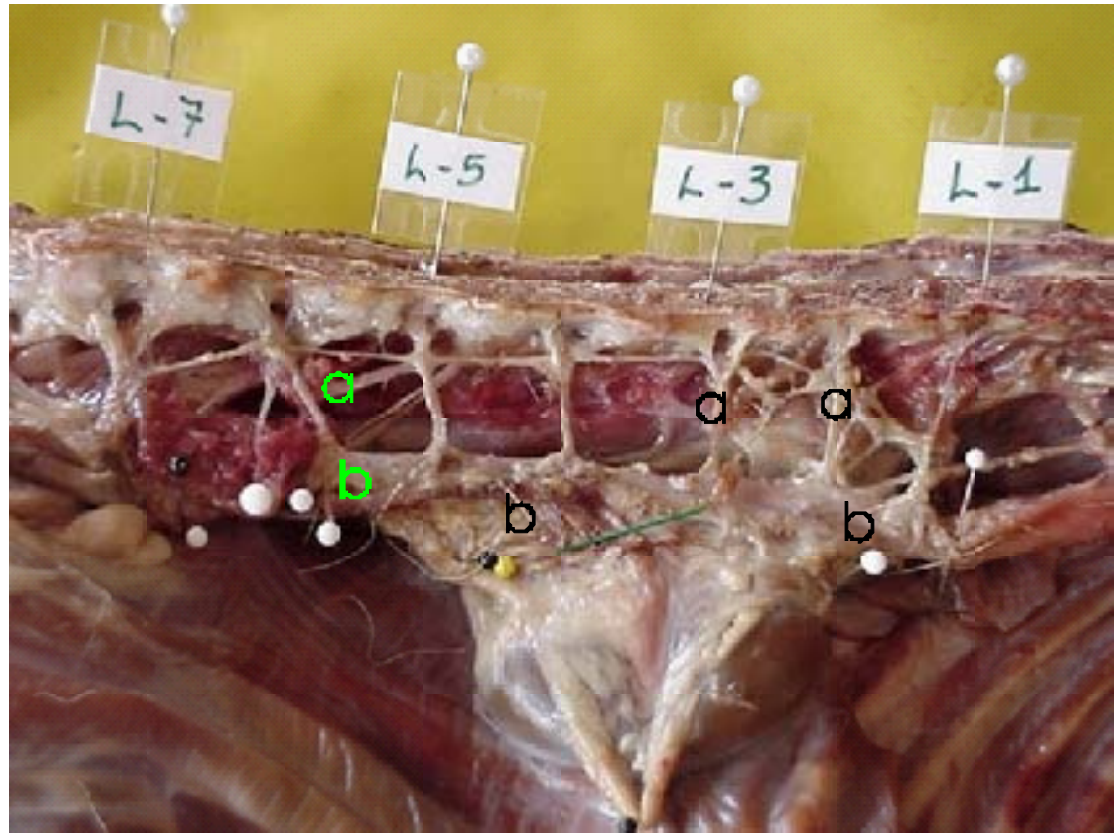

Figura 21 - Vista geral do tronco esplâncnico lombar do SNA e seus respectivos ramos (A), e plexos alvo (B). 


\section{DISCUSSÃO}

$\mathrm{Na}$ literatura consultada, poucos autores (DYCE, 1996; STROMBERG, 1993; GOSHAL, 1975; SANSON e REDDY 1982; KITCHELL, 1993; BENSON et al, 1996; CHRISMAN 1985; EVANS e KITCELL, 1993; deLAHUNTA, 1977) descreveram o aspecto anatômico das fibras autonômicas, quanto aos seus locais de origem das fibras e seus trajetos até órgãos alvo, pois descreveram apenas o aspecto funcional, que também reveste-se de importância, para atingir o objetivo proposto. No entanto, o aspecto anatômico se torna imprescindível como cita DYCE, 1996: "os trajetos dos troncos periféricos principais devem se reconhecidos para evitar riscos desnecessários durante cirurgias e protocolos anestésicos".

O nervo esplâncnico maior torácico se insinua na cavidade abdominal no nível de $T_{13}$, de acordo com STROMBERG, 1993, o que foi achado em todos os animais dissecados. (Fig. 3). Por outro lado, também se encontraram resultados semelhantes aos de STROMBERG, 1993, pois, em todas as peças os nervos esplâncnicos menores, deixaram o tronco simpático caudalmente ao nervo esplâncnico maior, que a esta altura emitia filamentos para a aorta e glândula adrenal e também vários ramos ao plexo celíacomesenterico. (Fig.4 e 5).

Após a ramificação deste plexo, já na região abdominal, o ramo simpático diminuía o tamanho de suas fibras, mas logo se tornava maior em diâmetro para seguir em direção caudal, aspecto já citado por STROMBERG, 1993. 
Quanto aos nervos esplâncnicos lombares, nesta pesquisa nenhum deles se apresentou duplo (STROMBERG, 1993 e GOSHAL, 1975).

Concordando com GOSHAL, 1975, o quinto, o sexto e o sétimo nervos esplâncnicos lombares dirigiam-se diretamente para o plexo mesentérico, emitindo fibras para o plexo mesentérico caudal e para os nervos hipogástricos como pode ser observado na Fig. 6.

Quanto aos gânglios e plexos abdominais, os aspectos anatômicos encontrados e que, estão de acordo com a citação de GOSHAL em 1975, foram os seguintes: o plexo adrenal possui uma rede adiposa densa envolvendo glândula adrenal e contendo suas fibras e os gânglios adrenais, distribuídos por todo o plexo e recebendo fibras do nervo esplâncnico maior e dos nervos esplâncnicos menores; o plexo celíacomesenterico como uma rede ao redor das origens da artéria celíaca e mesentérica cranial, contendo o gânglio celíaco e o mesentérico cranial, recebendo contribuições do nervo esplâncnico maior, menores e dos primeiros três nervos esplâncnicos lombares, fato este que encontra respaldo nas citações de STROMBERG, 1993 e observadas nas Figs. 5 e 7.

Os gânglios aórtico-renais se apresentaram intimamente ligados ao plexo celíacomesenterico, derivando, na maioria das vezes, de fibras do nervo esplâncnico maior, e do primeiro nervo esplâncnico lombar; o plexo mesentérico caudal origina-se da artéria mesentérica caudal, continuando, caudalmente, sem se interromper e ligando-se com o plexo pélvico, plexo este, que, talvez seja o mesmo mencionado por SANSON e REDDY em 1982, quando diziam que o nervo pélvico se expande em um "plexo" que 
também recebe o nervo hipogástrico. (Figs. 6 e 8). Os ramos viscerais seguem um trajeto análogo aos ramos da artéria mesentérica caudal, para a distribuição periférica.

Concordando, em parte, com o que descrevem os autores acima, obteve-se na dissecação a confirmação de KITCHELL, 1993, que para se alcançar o leito vascular, as fibras pós-ganglionares pegam "carona" no leito vascular, pois, na maioria das vezes, estas fibras se apresentaram "correndo" juntamente aos vasos de maior importância na região estudada.

Foram ainda encontrados resultados semelhantes aos descritos por CHRISMAN em 1985, pois, fibras nervosas se apresentaram saindo de suas raízes ventrais correspondentes para atingir e travar sinapses em tecidos alvo e glândulas abdominais conforme as figuras. (Figs. 9 e 10).

BENSON et al, 1996 e DYCE, 1996 descreveram, os processos periféricos dos corpos celulares das raízes ganglionares tóraco-lombar dorsais, alcançando o tronco simpático via ramo comunicante branco, percorrendo o tronco e alcançando vísceras através dos nervos esplâncnicos, fato este também observado nesta pesquisa.

MULLINGAN (1957) apud STROMBERG, 1993, cita que as fibras simpáticas terminam entre as fibras de colágeno, que envolvem os ligamentos abdominais no cão (p.e. ligamento lienovárico), opinião esta, que vai a favor dos achados nas dissecações efetuadas, onde estas fibras alcançaram, em todas as dissecações, diretamente a maioria destes ligamentos. (fig. 11) 
Quanto ao número exato dos nervos espinhais lombares, no cão, os resultados obtidos, estão de acordo com os citados GOSHAL, 1975, pois estes são em número de sete pares, e, no que diz respeito às suas divisões, sempre foram encontrados os dois ramos citados na literatura consultada, ou sejam, o ramo ventral e o ramo dorsal, sendo que os ramos dorsais se apresentaram bem mais delgados, conforme o citado também por EVANS e KITCHELL, 1993 e por DYCE, 1996. (Fig. 10, 12 e 13).

O tronco principal de cada nervo espinhal lombar, apresentou, na maioria das peças dissecadas, conexão com o tronco de nervos esplâncnicos lombares (simpático). Estas conexões foram citadas por EVANS e KITCELL, 1993 e chamadas por eles de ramos comunicantes que podem ir para um mesmo gânglio, fato este que ocorreu, também, em várias das peças dissecadas.

Observou-se ainda que, os ramos ventrais dos quatro últimos nervos lombares, acabam se unindo para formar o plexo lombar, como o descrito pela maioria dos autores. (DYCE, 1996; GOSHAL, 1975; KITCHELL, 1993; EVANS e KITCELL, 1993; STROMBERG, 1993). (Fig. 14, 15 e 16).

O nervo íleo-hipogástrico cranial emerge, ventralmente de $L_{1}$, invariavelmente, representando, então o primeiro par dos nervos lombares, conforme citado por GOSHAL, 1975. O mesmo fato ocorreu com a dissecação e identificação do nervo íleo-hipogástrico caudal, que se mostrou, invariavelmente saindo de $L_{3}$. (Fig. 17).

Comparado com a afirmativa de deLAHUNTA em 1977, de que os nervos lombares três, quatro e cinco contribuem para a formação do nervo 
femoral, encontrou-se, este fato ocorrendo, apenas com o quarto e quinto nervos lombares, não se encontrando evidência de contribuição do nervo lombar três para formar o nervo femoral. Por outro lado, confirmou-se o citado do autor quanto ao nervo genito-femoral saindo de $L_{3}$ e $L_{4}$; e nervo obturador de $L_{4}, L_{5}$ e $L_{6}$, fato que concorda com afirmações de EVANS e KITCHELL, 1993, e GOSHAL, 1975 que citam o nervo obturador surgindo do quinto e sexto espaços intervertebrais lombares.(Fig. 18, 19 e 20).

Os achados do nervo íleo-inguinal foram compatíveis com os descritos por EVANS e KITCHELL, 1993, e por GOSHAL, 1975, pois o nervo em questão foi encontrado emergindo de $L_{3}$ e emitindo seus ramos ventrais e mediais, e se comunicando com o quarto nervo lombar. Os achados foram compatíveis também com estes autores, pois o nervo genito-femoral sempre se apresentou como um ramo em separado do nervo femoral, surgindo sempre, do quarto espaço intervertebral. Por sua vez, o nervo femoral, se apresentou sempre surgindo do quinto espaço intervertebral, fato que confirma as afirmativas de BAILEY, 1988, em seu experimento, que encontrou o mesmo achado em cinco do total de 11 cães.

SCHIMIDT et al, em 1993, afirma que "a anestesia epidural promove completa analgesia e relaxamento muscular da metade posterior do corpo permitindo procedimentos cirúrgicos caudais ao diafragma". Quanto a esta afirmação, vale ressaltar que, com os resultados obtidos, anatomicamente nem todas as estruturas caudais ao diafragma teriam analgesia. Esta afirmação, em verdade, estaria ligada diretamente ao segmento lombar onde o agente anestésico local seria depositado. Por outro lado, esses resultados 
apóiam a afirmação de JONES, em 2001, que com a indicação deste tipo de anestesia promoveria analgesia para "alguns" procedimentos cirúrgicos ortopédicos em ossos longos, o que vai a favor de QUANDT e RAELINGS, 1996, onde citam que indicações de atos cirúrgicos, sempre, em estruturas pélvicas e caudais, podendo ser empregadas em cirurgias abdominais com protocolos e técnicas acuradas.

Os resultados confirmam a preocupação de INTELEZIANO et al, 2002, quanto aos efeitos deletérios e complicações da técnica epidural, visto a intimidade do nervo vago e tronco simpático torácico com as estruturas encontradas e identificadas na dissecação.

Por outro lado, MASSONE, em 1999, cita que a anestesia local peridural espinhal lombo-sacra em cadelas, não é suficiente para se efetuar uma ovariosalpingohisterectomia, pois, ao se pinçar o ligamento lienovárico o animal sente dor, fato este comprovado nesta pesquisa, pois está inervação depende da aferência de $L_{1}$ conforme se observa na figura 21 , e confirma a citação de MULLINGAN apud STROMBERG em 1957.

O que mais chama a atenção é de que a distribuição nervosa observada no organograma na página 60 mostra exatamente as estruturas nervosas que podem ser bloqueadas através de uma anestesia local lombosacra espinhal peridural contínua, evitando assim, possíveis desconfortos (dor), para o animal durante o ato cirúrgico. 


\section{CONCLUSÕES}

Frente aos resultados obtidos, na dissecação da inervação lombar observada, conclui-se que:

$E m L_{1}$ as emergências nervosas são:

- nervo esplâncnico lombar, contribuindo para formar o tronco esplâncnico lombar do sistema nervoso autônomo, que, através do plexo mesentérico cranial supre intestino delgado, ceco e intestino grosso; através do plexo intermesentérico supre gânglio mesentérico caudal e plexo pélvico, e, através do gânglio celíacomesenterico cranial direito, passando pelo plexo hepático supre pâncreas, duodeno, estômago e fígado; através do gânglio celíaco esquerdo supre baço, pâncreas e estômago; através do plexo adrenal supre diafragma e parte do peritônio abdominal, glândula adrenal, ovários, ovidutos e útero.

- nervo íleo-hipogástrico cranial.

$E m L_{3}$ as emergências nervosas são:

- nervo esplâncnico lombar, contribuindo para formar o tronco esplâncnico lombar do sistema nervoso autônomo, que, através do plexo mesentérico caudal supre nervos hipogástricos, cólon distal esquerdo, reto e plexo pélvico

- nervo hipogástrico caudal

- nervo íleo-inguinal

$E m L_{6}$ as emergências nervosas são: 
- nervo esplâncnico lombar, contribuindo para formar o tronco esplâncnico lombar do sistema nervoso autônomo

- emergência do nervo obturador

Existe interligação entre as emergências nervosas de $L_{4}, L_{5}, L_{6}$ e $L_{7}$ para a formação do plexo lombo-sacro que supre todas as estruturas músculo-esqueléticas do membro posterior. 
REFERÊNCIAS BIBLIOGRÁFICAS

BENSON, J.G; THURMON, J.C.; TRANQUILI, W.J. Lumb \& Jones Veterinary anesthesia. 3 ed. Willians \& Wilkins - Baltimore, 1996.

BONATH, K., GERLACH, K., HUBY, H. Der Periduralkatheter und seine Bedeutung fur die Peridual-anaesthesie und Schmerzbehandlung beim hund. Berliner und Munchener Tierarztliche Wochenschrift. 1984. 97: 1, 14.

BAYLEI, C. S.; KITCHELL, R.L.; HAGHIGHI, S. S.; JOHNSON, R. D. Spinal Nerve root origins of the cutaneous nerves of the canine pelvic limb. American Journal of Veterinary Research. 49: 115-119. 1988

BRADLEY, R.L.; WITNROW, S.J.; HEATH, R.B. Epidural anesthesia in the dog. Veterinary Surgery. 9: 153-156, 1980.

BROOK, G.B. Spinal anaesthesia in domestic animals. The Veterinary Record, 15(19): 549-53, 1935.

CUMMINGS,J.F. Thoracolumbar preganglionic neurons and adrenal innervation in the dog. Acta Anatomica. 73: 27-37, 1969

CUNNINGHAM, J.G. Tratado de fisiologia veterinária. 2 ed. Guanabara Koogan - Rio de Janeiro, 1999.

DeLAHUNTA, A. Neuroanatomy and clinical neurology. W.B. Saunders, 1977

DELLMAN, H. D.; McClURE, R. C. Sistema Nervoso Central dos carnívoros in: Anatomia dos Animais Domésticos, Robert Getty, 5 ed, vol 2. Guanabara Koogan - Rio de Janeiro, RJ, 1975.

DYCE, K.M; SACK, W.O; WENSIWG, C.J.G. Tratado de anatomia veterinária. 2 ed. Guanabara Koogan, Rio de Janeiro, 1996.

ERHART, E. A. Neuroanatomia. 5. ed. São Paulo: Ateneu

FLETCHER, T.F. Spinal cord and meninges in EVANS, H.E. Anatomy of the dog. 3 ed, 16, 800-806. W.B. Saunders, 1993

FUKAI, K. FUKUDA, H. Three serial neurones in the innervation of the colon by the sacral parasympathetic nerve of the dog. Journal of Physiology. 362:69-78, 1985 
GHOSHAL, N. G. Nervos Espinhais in: Anatomia dos Animais Domésticos, Robert Getty, 5 ed, vol 2. Guanabara Koogan - Rio de Janeiro, RJ, 1975.

GHOSHAL, N. G. Inervação abdominal, pélvica e caudal autônoma in: Anatomia dos Animais Domésticos, Robert Getty, 5 ed, vol 2. Guanabara Koogan - Rio de Janeiro, RJ, 1975.

HAGHIGHI, S.S. KITCHELL, R.L. JOHNSON, R.D. BAILEY, C.S.SPURGEON, T.L. Electrophysiologic studies of the cutaneous innervation of the pelvic limb of male dogs. American Journal of Veterinary Research. 52: 352-362, 1991

HASKINS, S. Problems and precautions when using epidural analgesia for surgery. Veterinary clinics of north America: Small Animal practice, v.22, n.2,p. 420-421, mar 1992.

HEATH, R.B. Lumbossacral epidural management. Veterinary Clinics of North America: Small animal practice, v 22, n 2, 417-419, 1992.

INTELIZANO, T.R; SANTOS, P.R.; FUTEMA, F.; OTSUKI, D.A.; ALMEIDA, T.A. Técnicas de Anestesia local - Anestesia epidural, in FANTONI, D.T.; - CORTOPASSI, S.R.G. Anestesia em cães e gatos. 19, 206-208. Roca São Paulo, 2002.

JONES, R.S. Epidural analgesia in the dog and cat. Veterinary Journal. 161(2):123-31, 2001.

KITCHELL, R. L.; EVANS, H.E. The Spinal Nerves in: EVANS, H.E. Anatomy of the dog. 3 ed, 16, 829-893. W.B. Saunders, 1993

MAILHAC, J.M.; CHAFFAUX, S.; ALVAREZ, R. Anesthésie epidurale chez lê chien. Recueil de Medicine Veterinaire. 1980. 156: 4, 277-282.

MASSONE, F. Anestesiologia Veterinária: Farmacologia e Técnicas. 3. ed. Rio de Janeiro: Guanabara Koogan, 1999. 225 p.

MULLINGAN (1957) apud STROMBERG, M. W. P. 1993, p. 778

CUMMINGS,J.F. Thoracolumbar preganglionic neurons and adrenal innervation in the dog. Acta Anatomica. 73: 27-37, 1969

PASCOE, P. Local and regional anesthesia and analgesia. Seminars in in Veterinary Medicine and Surgery, 12(2): 94-105, 1997. 
PURINTON, P.T., OLIVER, J.E., BRADLEY, W.E. Differences in routing of pelvic visceral afferent fibers in the dog and cat. Experimental Neurology. 73: 725-731, 1981

SANSON, M.D. REDDY, K. Localization of the sacral parasympathetic nucleus in the dog. . American Journal of Veterinary Research. 43: 18331836, 1982

SCHMIDT, G.V; OECHTERING, O.; Epidural anaesthesia in dogs and cats - still an alternative to general anaesthesia. Journal of Veterinary Anaesthesia, v 20, n 10, 1993.

SISSON, S.; GROSSMAN, J.D. Anatomia de los animals domesticos. 4 ed. Salvat, Buenos Aires, 1978.

STROMBERG, M. W. The Autonomic Nervous System in EVANS, H.E. Anatomy of the dog. 3 ed, 15, 776-799. W.B. Saunders, 1993

SWALANDER, D. B.; CROWE, D.T. J.; HITTENMILLER, D.H.; JANH, P.J. Complications associated with the use of indwelling epidural catheters in dogs: 81 cases (1996-1999). Journal of the American Veterinary Medical Association. 216(3):368-70, 2000 Feb 1.

TORSKE, K.E.; DYSON, D.H. Epidural analgesia and aesthesia. The Veterinary Clinics of North America. Small Animal Practice v 30, n 4, p 859$873,2000$.

WETMORE, L.A.; GLOWASKI, M.M. Epidural analgesia in veterinary critical care. Clinical Techniques in Small Animal Practice. 15(3): 177-88, 2000. 